\title{
Identifying non-agricultural marginal lands as a route to sustainable bioenergy provision - A review and holistic definition
}

\author{
Mellor, P. ${ }^{1,2}$, Lord, R.A. ${ }^{*}$, João, E. ${ }^{1}$, Thomas, R. ${ }^{3}$, Hursthouse, A. ${ }^{4}$ \\ $1=$ Civil and Environmental Engineering, University of Strathclyde, Glasgow, G1 1XJ, UK \\ $2=$ Present address Blackhall \& Powis Ltd., Glasgow, G2 1RW, UK \\ $3=$ WSP, Bristol, BS2 0 HQ, UK \\ 4 = University of the West of Scotland, Paisley PA1 2BE, UK \\ *=Corresponding author details, Richard.lord@strath.ac.uk
}

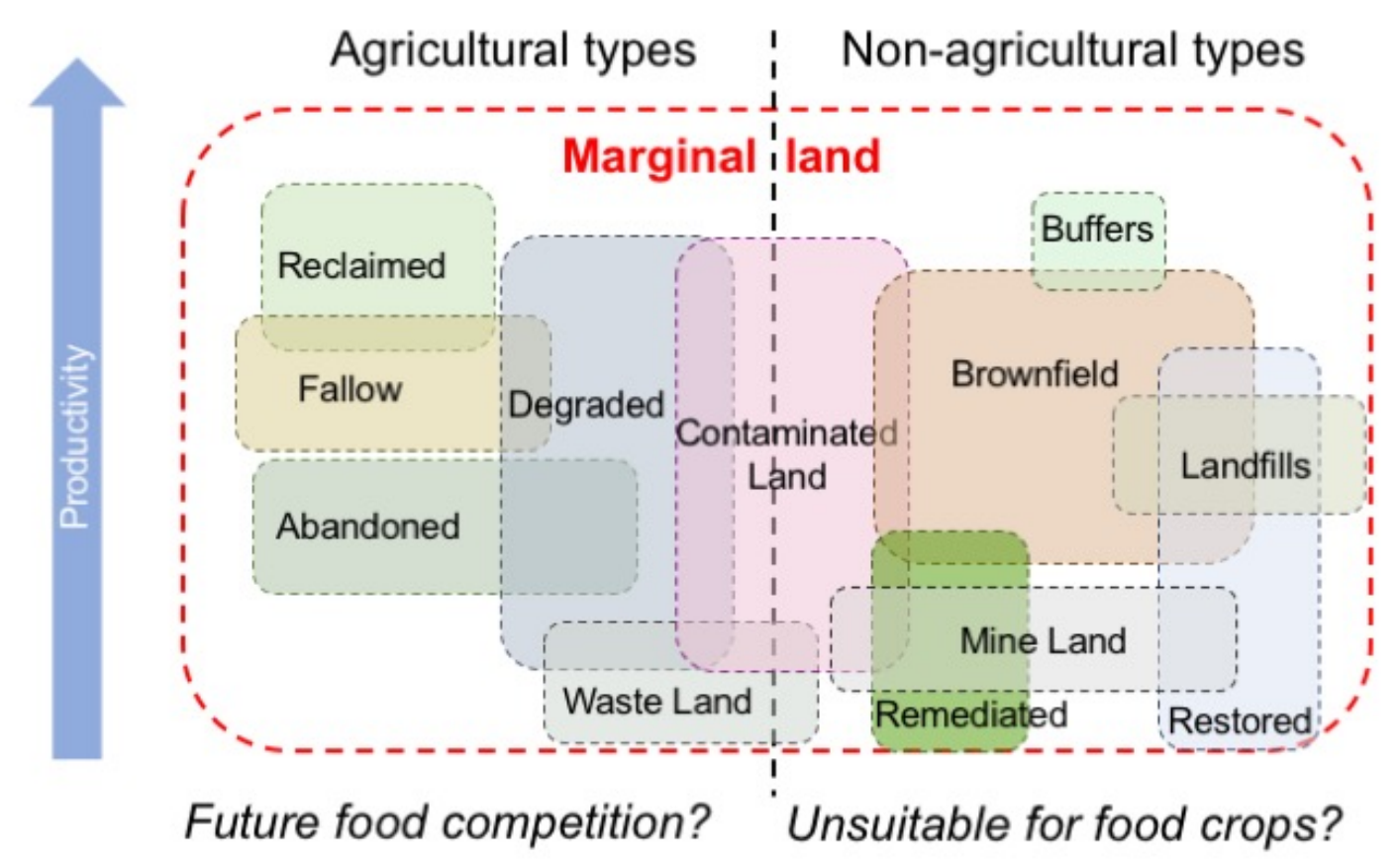

\begin{abstract}
Concerns regarding global food security, direct or indirect land use change from bioenergy production require a better understanding of the alternative landbanks that may exist. The potential of 'marginal' land, whether for food or fuel production, has been the subject of much previous research but is currently compromised by the lack of a clear, globally accepted definition. A critical omission in the plethora of existing explicit or implicit definitions in use is the lack of comprehensive or consistent inclusion of non-agricultural land types, here redefined as those now rendered unsuitable, unacceptable or permanently unavailable for food purposes. The result is variable inclusion of such land types in different areal studies, uncertainty regarding the nature of any land identified as 'marginal', in turn leading to inconsistent estimates of the role they could play in the provision of sustainable bioenergy.

The purpose of this research is to review the full range of possible 'marginal' land resources, especially those which are non-agricultural so avoid food competition, from previouslydeveloped brownfield land, to former landfills or old mineral workings. Literature examples are compared to determine which land types have actually been included and quantified. In
\end{abstract}


these case studies, non-agricultural types may equal other marginal lands at country or provincial scale, becoming dominant in urban regions. An inclusive definition is proposed, together with a graphic classification scheme, to guide future studies and enable quantification of truly non-agricultural marginal land as a potential contribution to sustainable bioenergy provision as part of the net zero, circular economy.

Highlights

- Inconsistent definitions or inclusion has neglected certain marginal land types

- Non-agricultural areas may equal other marginal lands types at regional scale

- Non-agricultural marginal lands may be $15-24 \%$ of urban regions

- Use for bioenergy could avoid food competition and (in)direct land use conflicts

Keywords: Biofuels; Indirect Land Use Change; Brownfield; Food versus fuel;

Word count: 9,769

Abbreviations: $\mathrm{MHa}=$ mega hectare $=10{ }^{6} \mathrm{Ha}$; 


\section{Introduction}

The importance of renewable energy in mitigating human induced climate change has long been established [1]. The necessity for change has been recognised by governments [2,3] and has impacted policy, driving research, development and rapid deployment of alternative, renewable energy technologies [4]. Having a broad energy mix is most likely to be the best method to achieve energy and climate change targets [5]. Bioenergy has been championed as a major contributor to this mix as a substitute to fossil fuels that can serve as a sink to capture and store atmospheric carbon [6]. Furthermore, bioenergy has been identified as a potential solution which could not only help mitigate climate change and provide energy security but also promote rural development [7][8]. Biomass can be readily substituted for fossil fuels, with the ability to utilise pre-existing power generation and distribution infrastructure [9], and is a versatile source of renewable energy, capable of providing both electricity and heat [10]. Demands for low carbon energy has seen global biomass production increase dramatically in recent years [11] and bioenergy currently represents $80 \%$ of the global renewable energy mix [9]. This demand is set to continue increasing as it is predicted bioenergy could supply up to a third of global primary energy supply by 2050 [12]. For example, biomass is currently the largest single source of renewable energy in the conterminous United States, with the largest future potential source predicted to come from growing dedicated energy crops on agricultural land [13]. When combined with carbon capture and storage bioenergy also offers a significant negative emissions technology, provided acceptable land resources for biomass production are available over suitable $\mathrm{CO}_{2}$ storage basins [14].

More biomass will be needed to achieve ambitious renewable energy and climate stabilization targets [11] but production and consumption must be sustainable if bioenergy is to be successful [6]. However, reaching consensus on a definition of biomass sustainability is both challenging and elusive $[15,16]$. A common theme for biomass to be considered sustainable is that it must be cultivated and harvested in a sustainable way, considering the full chain of production activities from growing feedstock to final energy conversion [17]. The sustainability of bioenergy is inextricably linked to its requirement for land for production, as an increasing demand for biomass inevitably leads to an increased demand for land on which energy crops could be grown [18]. The extensive spatial footprint of bioenergy [19] is problematical and it has become a priority to find locations where biomass can be grown sustainably.

For biomass to be considered sustainable it should deliver lifecycle greenhouse gas emission savings [20] and an important aspect of this is ensuring it is not grown on land with high carbon stock or biodiversity value [20]. Issues arise, however, when the conversion to agriculture or energy crops of land types with high carbon stock is considered [21]. As Fargione et al. [22] explain, the conversion of rainforests, peatlands, savannas, or grasslands to produce crop-based biofuels can create a 'biofuel carbon debt'. The amount of carbon dioxide released during this conversion has been quantified as 17 to 420 times greater than that saved in annual greenhouse gas reductions created by the displacement of fossil fuels [22]. Any large-scale land conversion for bioenergy crops will also have implications on global food security and existing ecosystem services $[23,24]$.

There are further concerns relating to the use of existing agricultural land for bioenergy production, as the use of fertile land currently in use for food crops leads to the clearing of 
carbon rich or biodiverse land elsewhere in the world to meet displaced demand for food crops [25]. This indirect land use change impact of bioenergy production can lead to biodiversity loss, rising food prices [25], and additional greenhouse gas emissions which lead to doubts about the climate benefits of bioenergy as a source of renewable energy [7]. Searchinger et al [26] warn that indirect land use change associated with increased corn-based ethanol demand could potentially lead to a doubling of greenhouse gas emissions in the next 30 years [26]. The credibility of such claims has been labelled an over-simplification, with counter claims arguing that carbon emissions associated with indirect land use change are far too complicated to be portrayed in pre-existing models and that the motivation for people clearing land cannot be so easily quantified [6,21]. However, the beneficial impacts of biomass crops, such as the carbon sequestration in soil and root biomass, are overshadowed once the effects of land use change, both direct and indirect, begin to be considered [27].

The challenge of identifying a suitable amount of land whilst also ensuring sustainable food production and environmental protection is known as the bioenergy land use dilemma [28]. As outlined above, land use decisions relating to biomass production can have significant effects on carbon sequestration, native plant diversity, food production, greenhouse gas emissions, water, and air quality [6]. It has been argued that a requirement for sustainable biomass production is not only the avoidance of carbon rich areas but avoidance of agricultural land that would otherwise be used for food production [7]. The consideration of land types that are not used for food provision would not only strengthen food security [23] but has also become an imperative to realise the greenhouse gas emission savings that bioenergy could provide [6]. For these reasons studies have emerged highlighting the need to further an understanding of the role idle, abandoned, or degraded land types could play in bioenergy provision [7,29] and these land categories have since become associated with the term 'marginal' land.

The aim of this paper is to critically assess the evolving concept of 'marginal' land with respect to its potential to deliver sustainable bioenergy provisioning services. In particular, the focus is on the range of non-agricultural land types that have, or perhaps should, be included in existing, or future, areal studies of marginal land. The working hypothesis is that truly "nonagricultural" land areas can be identified which offer an alternative to future direct competition with food production or indirect land use change from utilising marginal agricultural land.

\section{Materials and methods}

A review of published academic literature was used to achieve two objectives: Firstly a critical review of the theoretical development of the marginal land concept, the changing use of the term, purported benefits of using this land resource, limitations and problematic nature of the terminology; secondly, a quantitative (i.e. land areas) and qualitative (i.e. land types) evaluation of marginal land resource assessment studies that have included non-agricultural land types. From these a comprehensive taxonomy and summary of the unique advantages and challenges of using these land resources have been compiled.

The initial data review was conducted between 2014 - 2018 [30], considering any articles written within the last 20 years, then updated in late 2019 and early 2020. A combination of Google Scholar and Scopus were searched using the Boolean search terms 'bioenergy' OR 'biomass' OR 'biofuel' AND 'availability' AND 'marginal land' to locate studies assessing the availability of marginal land. The methodology sections of selected articles were scrutinised to identify the types of land that were included. Only those studies that specifically considered 
non-agricultural land were considered further. For example, those using any of the following keywords: 'vacant', 'derelict', 'abandoned', 'mine land', 'landfill', 'brownfield' and 'buffers'.

For each case study the qualitative data collected were the location, the definition of marginal land employed and a list of the non-agricultural land types that have been included. This was also used as the basis of a new graphical classification scheme. Quantitative data were compiled on the area of all types of marginal land and the area of non-agricultural land types. These were used to calculate the relative importance of agricultural and non-agricultural types as a percentage of all marginal land and of the total area of land considered.

\section{Theory of 'marginal land' - a critique and proposed revision of the state-of-the art}

\subsection{Emergence of the 'marginal' land concept}

According to Smit et al. [31], the marginality of land 'relates fundamentally to the economic viability of land uses' and can be used to define areas in agriculture which have limited productive potential. The term 'marginal' land originally emerged from the field of agricultural economics in the 19th Century [32], with Ricardo [33] using the categorisation in his land rent theory, which became the foundation of marginal productivity theory. Marginal lands were at the 'margins of cultivation' [34], at the margin of economic viability [35], and 'where costeffective production is not possible under given conditions' [36]. For example "Marginally Suitable") was the United Nations Food and Agriculture Organisation's lowest Land Suitability Class (S3) defined as "Land having limitations which in aggregate are severe for sustained application of a given use and will so reduce productivity or benefits, or increase required inputs, that this expenditure will be only marginally justified." [37]. These three core aspects of severe limitations, the requirements for additional inputs and the marginal net benefit obtained became part of the definition of marginal land proposed by the UN Consultative Group on International Agricultural Research, to which were added "Limited options for diversification..." and "...risks of irreversible degradation." [38] The definition compared marginal with favoured, fragile and degraded land types on the basis of biophysical and socioeconomic constraints [39]. Thus, whilst land was originally deemed marginal purely from an economic perspective, the definition of marginal land broadened to include environmental factors such as soil health and topography [27]. Increasingly marginal land has become an 'umbrella term' to describe idle, barren, degraded, abandoned and underutilised lands [40] with the concept evolving across time, space and discipline [32].

\subsection{Visualising marginal and related land types}

Several authors have attempted to illustrate the concept of marginal land and its complex relation to other similar land types using Euler diagrams [29,40,41]. Comparison of these examples reveals subtle differences in how marginal lands are viewed by different authors in the context of bioenergy production (Fig. 1). 
Fig. 1. Variation in diagrams used to illustrate land that could be considered 'marginal' compared to other similar or overlapping types. a) An early (2008) schematic diagram according to Wiegmann et al. [29]. b) An alternative later (2012) diagram according to Dauber et al. [40], with reclaimed land now included. c) Further land types that have been considered as marginal land for potentially growing dedicated energy crops according to Blanco-Canqui [42]. d) A more recent (2016) schematic diagram, now including brownfields, used by SEEMLA [41] to contextualise conditions of four pilot sites. Adapted from [29], [40], [42], and [41].

a)

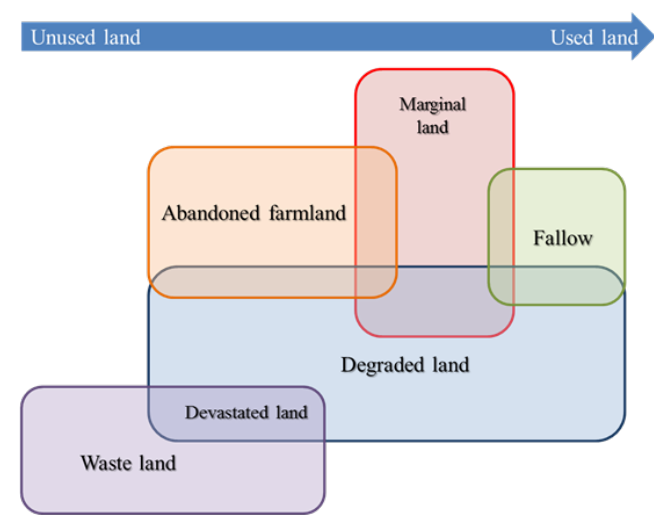

c)

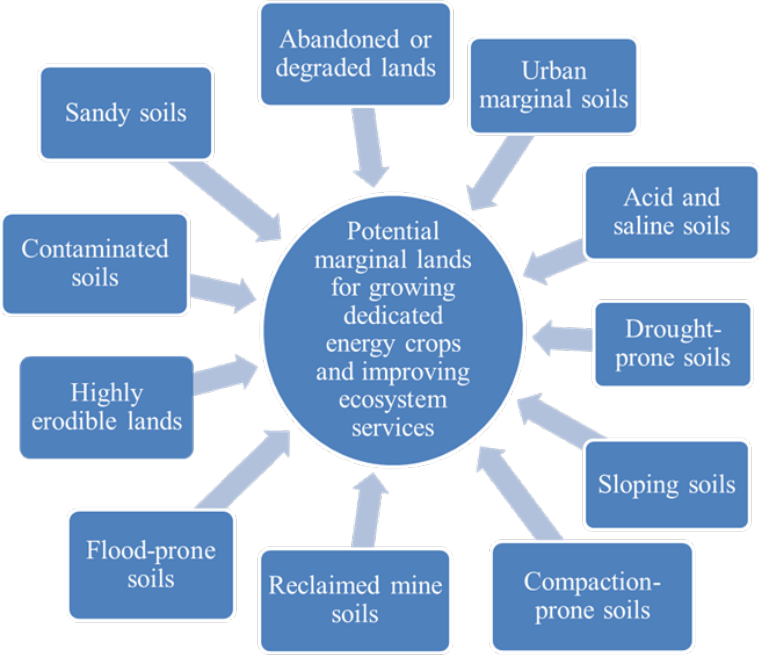

b)

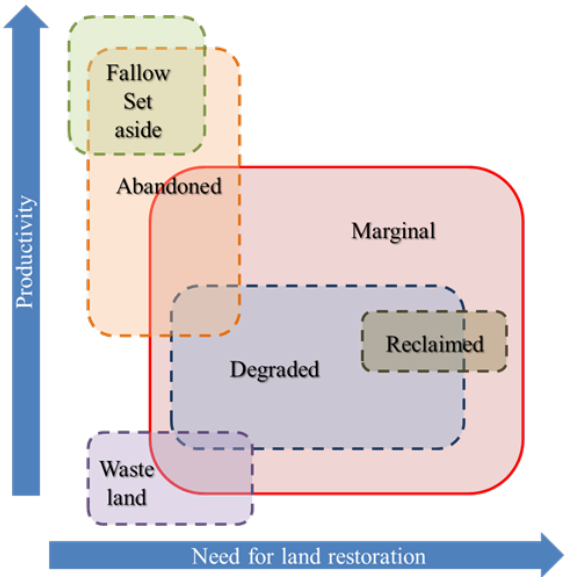

d)

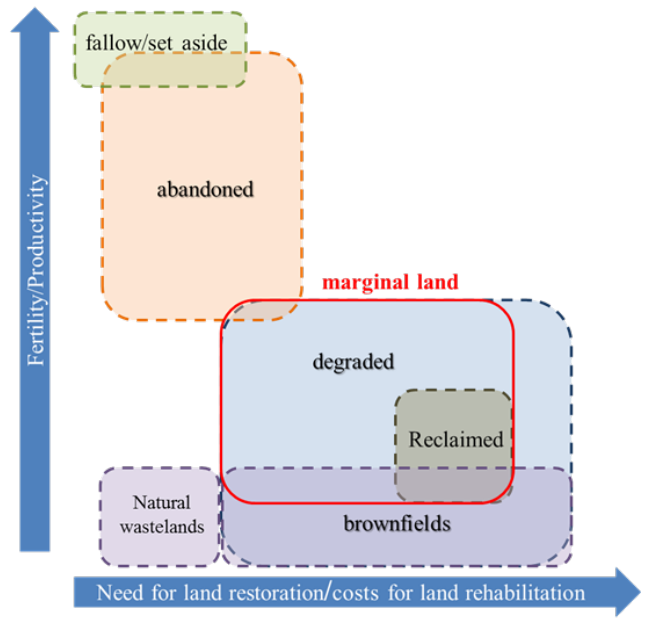

\subsubsection{Marginal lands}

Wiegmann et al. [29] define marginal land in terms of land economics, which they depict as partially overlapping degraded, abandoned and fallow land (see Fig.1a). In contrast Dauber et al.'s [40] version (Fig. 1b) represents marginal land as fully encompassing degraded and reclaimed land types, whilst separate from fallow and set aside lands. More recently, the EU funded SEEMLA project 'Sustainable Exploitation of Biomass for Bioenergy from Marginal Land' [41] has adapted Dauber et al.'s [40] figure to contextualise the condition of four pilot sites [41]. In the new figure (Fig. 1d) marginal land no longer fully encompasses degraded land and now includes some brownfield sites. Finally, Blanco-Canqui et al. [42] present an illustration (Fig. 1c) that suggests potential marginal lands for growing dedicated energy crops could include an even wider range of land types from urban marginal soils to contaminated soils. These studies, and their associated schematic diagrams, illustrate the variability in how marginal land is defined, its increased prominence in classification schemes and the tendency 
for it now to be understood as more of an umbrella term than the initial economic definition intended.

\subsubsection{Fallow land or set-aside}

Fallow land is temporarily unused farmland if during part of a crop cycle [29] but is set-aside land if this is due to political intervention [40]. It overlaps with marginal land in Fig 1 (a), whereas fallow/set aside sites are grouped together in (b) and (d), shown overlapping with abandoned land but not considered marginal. So, a fallow land area might be considered marginal under (a), even if not abandoned or degraded but would be excluded from marginal land if using either schemes (b) or (c).

\subsubsection{Abandoned land (farmland)}

In abandoned farmland agricultural activities have ceased for economic, political or environmental reasons [29,40]. For land that had been farmed but is now permanently abandoned this could be because it is either degraded, marginal, both or neither in scheme Fig 1 (a), whereas in scheme (b), it could be neither, both or just marginal. However, in (d) it would only be considered marginal land if it was also degraded.

\subsubsection{Waste lands}

These are natural lands rendered permanently and naturally unusable by unfavourable physical and biological conditions [29]. If they are also degraded then they are referred to devastated in Fig 1(a). Some waste lands are included as marginal land in (b), which may or may not also be degraded, but are excluded in (a). In (d) wastelands are separately classed as "natural" so do not include degraded land, nor are they ever considered as marginal lands.

\subsubsection{Degraded lands}

Degraded lands [38] are in essence those where current productive use has been limited anthropogenically, although definitions vary [29,40]. In Fig 1 (a) these are regarded as a separate class, potentially overlapping with either abandoned, marginal, fallow or waste lands. In contrast, all degraded lands would be considered as marginal in scheme (b), together with most of those that were not also brownfields in (d). Thus, degraded areas might all be included or some excluded from marginal land if using different schemes.

\subsubsection{Brownfields}

Brownfields are previously-developed areas that may or may not be affected by potential contamination issues, depending on the respective national definition [43]. Brownfields are only considered separately in Fig (d), here as a subset of degraded land. Presumably they are either not considered in schemes (a) or (b), are not distinguished from other types of marginal land, so would not necessarily be included as marginal land.

\subsubsection{Reclaimed lands}

Reclaimed lands are strictly those recovered from below water level by land-raising, but in this context have also referred to those restored after mining or other non-agricultural use [40], possibly including remediated brownfields or contaminated land. Reclaimed lands are only shown in Fig 1 (b) and (d) they are shown as a subset of marginal lands in both cases but may not be degraded in (b) and could be from the restoration of brownfields in (d). 


\subsubsection{Implications of inconsistent schemes}

The descriptions and scenarios above show that the subtle differences observed between graphical schemes are substantive. It may be noted that the number of categories used increases from 5 through 6 to 7 over an 8 year period for the sources cited, which may indicate attempts to refine and adjust the classifications sequentially. Although these each offer a useful visual aid of the marginal land paradigm, in an operational context the subtle differences between them would lead to the same land parcel being classified differently using different schemes. Critically, this might also lead to variability in whether it was classified as marginal lands or included in any areal survey thereof.

\subsection{Purported benefits of marginal lands for bioenergy}

Regardless of the definition employed, studies tend to reference a similar set of potential benefits of using marginal land for bioenergy provision. It is argued that because marginal land is largely unsuitable for agriculture it could avoid many of the competition effects of direct and indirect land use change which is currently bringing the sustainability of bioenergy into disrepute [10]. Fargione et al. [22] have even claimed that if biofuels are from biomass waste or perennial crops grown on abandoned and degraded agricultural lands they 'incur little or no carbon debt and can offer immediate and sustained greenhouse gas advantages' [22]. In cases where marginal land has poor vegetation cover it has been suggested that utilisation for energy crop purposes can increase the amount of sequestrated carbon in soil and root biomass [27,44]. If non-agricultural lands are amended with organic waste material these can provide decadal benefits, easily exceeding the requirements of 4 per mille initiative and the Paris agreement [45]. Furthermore, it has been proposed that utilising these marginal lands can enhance their environmental condition [6] by improving soil fertility, reducing degradation, reducing wind and water erosion and providing biodiversity conservation [10,42,46,47] and habitat quality benefits [48]. Studies have also claimed that utilising marginal lands could bring additional societal benefits such as increased rural employment and improved scenery and infrastructure $[6,46]$.

\subsection{Attempts to quantify 'marginal' land}

As Lewis and Kelly [28] point out, since 1993 there has been a large increase in the number of papers addressing terms such as marginal lands and biofuels in combination with methodological terminology including GIS and spatial data analysis. Such attempts have taken place at various scales, using a variety of models and data inputs [28]. There are a number of studies that have attempted to identify the availability of marginal land at the global level [4952]. The earlier of these studies [49,50] compare past and current land cover using a global scale database to identify abandoned agricultural areas. Cai et al. [51] attempted to apply land suitability indices based on soil productivity, topography, soil temperature regime and humidity. These indices were then combined with land cover mapping in an attempt to understand the current land use of areas deemed marginal based on the land suitability indices. As Lewis and Kelly [28] argue, these global scale studies are challenged by the availability of up-to-date datasets at a suitable resolution. Similar obstacles exist for the growing number of studies seeking to identify the amount of marginal land at a national or regional level. There have been a few attempts to identify marginal land nationally: Studies have considered the United States [53] and Australia [54], with several seeking to understand the extent of this resource in China [46,55-61] due to this country's pressing need to avoid growing bioenergy 
crops on agricultural land [28]. There have also been a range of studies at a regional scale, in particular several assessments have been attempted in the United States [27,62-67] and Italy [68-70]. Fewer studies so far have applied these methods in developing countries. Milbrandt et al. [71] conducted a semi-global assessment of the provision of marginal land in AsianPacific Economic Cooperation countries which included developing countries of South-East Asia. Studies have also investigated the availability of marginal land in Sub-Saharan Africa [72] and India [73,74].

\subsection{Ambiguities in 'marginal' land definitions}

A number of other researchers have underlined key issues and related assumptions [75] with the term that brings into question its role as a sustainable option for bioenergy production or hampers attempts to identify the land resource. The most pronounced problem is related to the variation and ambiguity in its definition or understanding. The definition varies widely according to country, local conditions and the organisation or institution studying the issue $[21,76,77]$, while the underlying concept of marginal lands has evolved and been used interchangeably with other terms [32]. Often the classification schemes used to identify marginal land (such as shown in Fig. 1) vary significantly leading to various interpretations as to what land types can be classed as marginal. As Wicke [10] explains, the vagueness of the classification of this land type leads to practical difficulties in identifying marginal land. This, coupled with dissimilarities in model and datasets applied [28], has led to a wide range of estimates regarding the availability of land for growing dedicated energy crops [78]. In the UK, for example, published estimates of the extent of marginal land resource range from 362,859 ha [23] to 3.1 Mha [79]. Moreover, Glithero et al. [78] consider these estimates to be maxima, given the limited number of farmers who would actually be willing to take up energy crop production in the current context of dedicated energy crop growth in England. The marginal land label further dissuades farmers from involvement as they are keen not to pronounce their land as being marginal 'enough' for this purpose only [80]. The various ways in which the term has been approached makes comparisons of studies difficult [7] and therefore the appropriateness of the land resources identified are brought into question. Wicke [10] argues that the ambiguity of the definition must be removed by the establishment of clear criteria and a methodology for identifying land that is sustainable for bioenergy production. At present this is lacking in the marginal land discourse which leads to questions regarding the certainty of identified land being an acceptably sustainable solution to the bioenergy land use dilemma.

Shortall [75] identifies three dominant definitions of the term marginal land and outlines the problematic technical, normative, and political assumptions that are embedded within each of them: The first two definitions - that marginal land represents either 'land unsuitable for food production' or 'ambiguous lower quality land' share the same assumptions. Both assume that there is enough of these land types, that production is possible on them, and that they can be targeted [75]. However, such assumptions are particularly problematic when the definition still contains a degree of ambiguity and could still represent several different land types from the most degraded agricultural land to brownfield land. The third definition, that marginal land is 'economically marginal land' has a different set of assumptions and related problems. Shortall [75] explains that it is assumed that using economically marginal land for bioenergy production is possible in a sustainable way without competing with food production. However, the author points out that using land types such as grade 3 or 4 (i.e. good to moderate, or poor) agricultural land would, in fact, still lead to the displacement of some food production [75]. Similarly, Kang 
et al. [32] argue that marginal land already plays an important role for agriculture, noting that it was the primary factor behind a $25 \%$ increase in global wheat production in 1997. It is the temporality and variability of the economic based definition that is particularly challenging when trying to gain an understanding of the role marginal land could play in providing sustainable bioenergy. Li et al [81] argue than marginalization of agricultural land may be a dynamic effect consequent on rapid urbanization in China. Shortall [75] explains that what is considered marginal for one crop under one set of economic conditions may not be marginal for another crop or in other conditions, since what is at the economic margin of production at one point in time may be considered not marginal as prices of harvesting, transport or production fluctuate. Dauber et al. [40] touch on a similar theme by arguing that using land that is temporarily idle could still be contributing to indirect land use change if that land could have come back into use for agriculture at a later date. Evidentially, there is a lack of clarity with regards to the type of land that is being referred to in many studies and, as Shortall [75] concludes, depending on the definition employed, using marginal land could be arguably either unfeasible, due to poor quality land, or unsustainable, due to a continuation of detrimental land use change.

\subsection{Problems identifying and using 'marginal' land}

From an operational perspective, marginal land poses a challenge to identify. Dale et al. [21] discuss the difficulty in utilising satellite imagery to find marginal land. This is made even more difficult if the definition of the resource sought remains ambiguous. It is often assumed that land is idle [10] yet it is problematic to assume this from land cover data or poor resolution satellite imagery. Some uses are particularly difficult to identify such as grazing or fuelwood collection [40]. Lewis and Kelly [28] state that hard-to-detect land uses can often not be captured via remote sensing which ultimately leads to them being left out of broad scale geospatial datasets. This is of particular concern when the often wide-reaching definition of marginal land is taken into consideration and could arguably lead to fears that some land types are being overlooked. A recent review of methods used in marginal land assessment suggested that biophysical and socio-economic factors needed to be qualified by consideration of qualitative data, such as the landowner's perspective on whether the land was marginal [82].

Regardless of the definition employed there are additional practical problems that have been discussed in the literature in relation to the use of marginal land for bioenergy production. At the forefront of these issues is the condition of land types being included as marginal land. The 'law of marginality' as described by Lal [83] states that marginal soils will produce marginal yields. Gelfand et al. [64] also highlight the problematic nature of identifying land with low fertility. The impact of selecting marginal land is quantified by Fischer et al. [84] who claim that yields are up to three times greater on suitable soils. Dauber et al. [40] add that often land is deemed marginal because of a lower yield potential based on a lack of precipitation, therefore utilising such land could result in a large water footprint. In addition to the issue of land quality, it has been argued that marginal lands are poorly located [64] and that the long distances needed to reach them could mean the loss of carbon dioxide neutrality of any energy produced [40]. These highlighted problems lead to doubts over the sustainability of marginal land for bioenergy crop production and, because of the umbrella nature of the terminology used, often several, vastly different, land types are considered to share the same limitations.

\subsection{Redefining 'marginal' land to include non-agricultural types}


To address these shortcomings and in the absence of a suitable alternative this paper proposes the following new working definition for future studies: "Marginal land is any identifiable land area, whether originally agricultural or non-agricultural, including those in urban areas, which is currently unused or underutilised due to economic, environmental or social factors, but which is suitable for temporary or longer term use for sustainable energy production".

The schematic diagrams, of previous studies [29,40-42] can be adapted and combined as shown (Fig. 2) to aid use as a practical tool and taxonomy, highlighting the wide range of categories of land worthy of consideration. Non-agricultural and agricultural marginal lands are considered to be mutually exclusive and not readily transmutable, while accepting that both may be either contaminated or waste lands. Agricultural land is that which, was, is or could conceivably in the future be used for agriculture, which is in turn defined by the UK 1947 Agriculture Act [85]. Thus, the categories on the left-hand side of Fig. 2 can be considered as agricultural land resources, land that is currently, has been, or potentially could be, used for food production. It must be emphasised that low productivity areas not currently used for food production are include here as agricultural marginal lands (i.e. unused agricultural or other natural lands, including all natural waste lands), whereas these have been referred to as 'nonagricultural' by others ( e.g. [11]). The various other types of naturally or agriculturally compromised soils or lands shown in Fig.1 (c) [42] (i.e. sandy, sloping, acid or saline soils, highly erodible land, drought-, compaction- or flood-prone soils) are not shown separately but would also fall within the agricultural part of the marginal land field of Fig. 2 and might overlap with waste land, abandoned or degraded types. The bulk of waste lands are included here with agricultural types, as these are areas that have naturally limited productivity due to physical and biological conditions [29], such as active dunes, salt flats, rocky outcrops, deserts, ice caps and arid mountain regions, but might conceivably become agriculturally productive in future [40]. In contrast, in this scheme only the categories on the right-hand side can be considered as truly non-agricultural land resources, land now rendered unsuitable for food production anthropogenically, or having a regulatory and/or protected status which prevents its use for food production. The diagram is designed to illustrate the possible overlap or exclusion between categories, so is topological, as the fields cannot also be drawn to scale. 
Fig. 2. Proposed schematic diagram showing included land categories in terms of productivity and agricultural potential. The categories on the left-hand side can be considered agricultural land resources, land that is currently, has been, or potentially could be, used for food production.

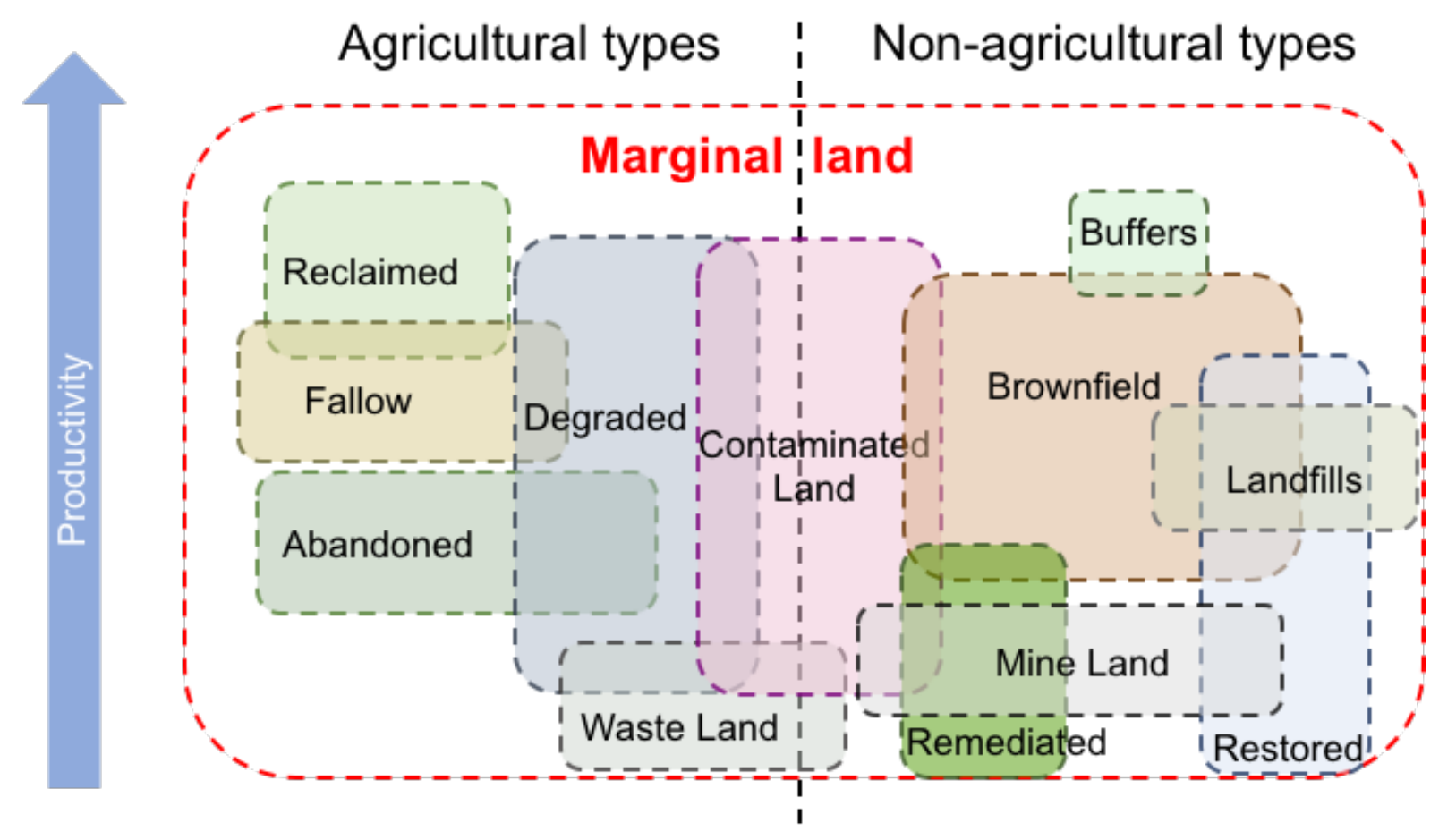

\section{Results \& discussion}

\section{1 'Marginal' land studies which included non-agricultural land types}

The extent to which non-agricultural land types are considered by previous research to contribute to the availability of marginal land was determined using the literature review. Some publications stick strictly to an economic-based understanding of marginal land, which leads to a focus on only marginal agricultural lands $[54,60,69,86,87]$ or selection of lands only from an agricultural land classification dataset $[23,70,88]$. These studies make no attempt to include non-agricultural land types in their assessment of marginal land. Global scale studies deal with datasets at such a resolution that it is difficult to determine which land uses are included $[28,89]$. This is not intended to be a criticism of such global studies [49-52,71]. It is simply meant to highlight that it would not be possible to determine what proportion of the marginal land these studies identify is non-agricultural, based on their use of global land cover datasets. Additionally, the identification of degraded land, a term associated with marginal land related to a loss of productivity potential [90], has been attempted via a top-down assessment using the HYDE (History Database of the Global Environment) database [56]. This type of assessment, based on a historical global environment database, shares the limitation of producing an output from which it is challenging to distinguish identified land types, as well as further concerns that the degraded area identified may be in use or have a high biodiversity value [40]. Lastly, some studies seeking to identify marginal land based on land cover classification or physical and environmental characteristics simply fail to go into sufficient detail regarding the current use of lands identified $[63,64]$.

These global scale studies, land degradation studies based on global datasets, and studies that fail to clarify the land use of identified areas were not considered any further in this assessment 
of non-agricultural land inclusion in marginal land research. Furthermore, whilst abandoned agricultural land has been included as a marginal land type in some research [66,91], it was not considered to be a source of non-agricultural land in this review. This is due to the previously highlighted risk that idle farmland could come into use for agriculture in the future [40], therefore potentially causing indirect land use change if committed to bioenergy. Finally, considering the requirement to find a sustainable alternative to agricultural land, land types with the potential to have a high carbon stock or biodiversity value, such as shrubland or grasslands, were also not included as a suitable non-agricultural land resource, even if they were deemed to be marginal and not in use for food production. Turley et al. [92], for instance, include hedgerows and lowland bracken as an idle land resource but these were not included here. This stipulation led to the exclusion of further studies who seemingly only identified these highly vegetated or potentially bio-diverse land types [55].

After an evaluation of the marginal land literature 16 studies were found that explicitly include quantitative data for types of non-agricultural land and these are set out in Table 1. These studies were published between 2009 and 2018 and include eight studies conducted at a national scale, six at a regional scale and two at the local, or city, scale. Of these studies, nearly half consider land areas in emerging economies, albeit 6 were in China and one in India. The remainder are for all or part of three developed countries (USA, UK, Italy).

The definition of marginal land applied by each study varied. It should be borne in mind that these were each selected specifically because they had included the assessment of nonagricultural land types. Seven of the studies stipulated that marginal land must not be suitable for food-based agriculture $[27,58,59,61,65,67,93]$. However, a further four studies still specify marginal land as that which is not 'currently' available or not cost effective for agriculture [57,62,68,92]. Again, this raises the issue of the temporal nature of marginality. The different approaches taken often lead to plain contradictions. For instance, Gopalakrishnan et al. [27] include conservation land as a source of marginal agricultural land which contrasts with the definition of Niblick and Landis [93] that marginal land must not be 'otherwise fulling conservation purposes'. Two of the studies, at the local or city scale, specified the inclusion of 'urban marginal lands' [65,94]. This led to the identification of various non-agricultural land types that may be found within the urban limits, such as vacant lots, land surrounding developed lots and underutilised areas. In contrast to this Milbrandt et al. [53] exclude all urban areas from their study. It is clear that a more consistent approach is required.

Beyond urban marginal land a wide spectrum of non-agricultural or other marginal land types has been considered. Most of the research conducted in China has included 'barren' and 'bare land', which includes shoal, bottomland, saline land, alkaline land [57-59,95] and, in one case, sand marsh and marsh land [61]. It is unclear how appropriate these land types would be for dedicated energy crop production, as in addition to poor biophysical conditions they may be inaccessible. One study in China [46] includes several additional non-agricultural land types, such as roadside land, stream side land, house surroundings and land risers or boundaries. This inclusion of buffer strips along infrastructure such as roads, rivers, rail, or canals has been mirrored in several other studies $[27,53,62,92]$. 
Table 1: Summary of areas of 'marginal' land found in studies that included non-agricultural land types.

\begin{tabular}{|c|c|c|c|c|c|c|c|c|c|c|}
\hline Year & Author & Area & Scale* & $\begin{array}{l}\text { Marginal Land } \\
\text { Definition }\end{array}$ & $\begin{array}{l}\text { Non-agricultural } \\
\text { land types }\end{array}$ & $\begin{array}{l}\text { Non- } \\
\text { agricultural } \\
\text { land area } \\
\text { found } \\
\text { (Mha) }\end{array}$ & $\begin{array}{l}\text { Total } \\
\text { marginal } \\
\text { land } \\
\text { area } \\
\text { found } \\
\text { (Mha) }\end{array}$ & $\begin{array}{l}\text { Proportion } \\
\text { of marginal } \\
\text { land found } \\
\text { that is non- } \\
\text { agricultural } \\
(\%)\end{array}$ & $\begin{array}{l}\text { Non- } \\
\text { agricultural } \\
\text { land as } \\
\text { proportion } \\
\text { of total land } \\
\text { area }(\%)\end{array}$ & Comments \\
\hline 2009 & $\begin{array}{l}\text { Gopalakrishnan } \\
\text { et al [27] }\end{array}$ & Nebraska & $\mathrm{M}$ & $\begin{array}{l}\text { Land not } \\
\text { suitable for } \\
\text { productive } \\
\text { agriculture, } \\
\text { which require } \\
\text { inputs of water } \\
\text { and nutrients to } \\
\text { maintain } \\
\text { productivity }\end{array}$ & $\begin{array}{l}\text { River/riparian } \\
\text { buffers; road } \\
\text { buffers; brownfield } \\
\text { sites }\end{array}$ & 0.65 & 1.25 & 51.8 & 3.23 & $\begin{array}{l}\text { Brownfield } \\
\text { deemed } \\
\text { 'insignificant' } \\
\text { and total } \\
\text { includes } \\
\text { conservation } \\
\text { land }\end{array}$ \\
\hline 2010 & Tang et al. [46] & China & $\mathrm{L}$ & $\begin{array}{l}\text { Land that may } \\
\text { be used for } \\
\text { growing energy } \\
\text { crops such as } \\
\text { wasteland and } \\
\text { paddy fallowed } \\
\text { in winter, plus } \\
\text { land risers, land } \\
\text { boundaries and } \\
\text { land along } \\
\text { highways/roads }\end{array}$ & $\begin{array}{l}\text { Wasteland, land } \\
\text { riser/boundary, } \\
\text { stream side land, } \\
\text { house } \\
\text { surroundings, land } \\
\text { along } \\
\text { highways/roads }\end{array}$ & 55.65 & 110 & 50.6 & 5.8 & \\
\hline 2010 & $\begin{array}{l}\text { Turley et al. } \\
{[92]}\end{array}$ & $\begin{array}{l}\text { England and } \\
\text { Wales }\end{array}$ & $\mathrm{M}$ & $\begin{array}{l}\text { Land where cost } \\
\text { effective } \\
\text { agricultural } \\
\text { production is not } \\
\text { possible under a } \\
\text { given set of } \\
\text { conditions }\end{array}$ & $\begin{array}{l}\text { Land resources } \\
\text { with no current } \\
\text { agricultural value: } \\
\text { roadside verges; } \\
\text { railway } \\
\text { embankments; } \\
\text { canal margins; } \\
\text { brownfield land }\end{array}$ & 0.6 & 4.34 & 13.8 & 3.96 & \\
\hline
\end{tabular}




\begin{tabular}{|c|c|c|c|c|c|c|c|c|c|c|}
\hline 2011 & $\begin{array}{l}\text { Zhuang et al. } \\
\text { [57] }\end{array}$ & China & $\mathrm{L}$ & $\begin{array}{l}\text { Relatively poor } \\
\text { natural condition } \\
\text { but is able to } \\
\text { grow energy } \\
\text { plants, or land } \\
\text { currently not } \\
\text { used for } \\
\text { agricultural } \\
\text { production }\end{array}$ & $\begin{array}{l}\text { Barren land } \\
\text { (shoal/bottomland, } \\
\text { saline and alkaline } \\
\text { land, and bare land) }\end{array}$ & 5.21 & 130.34 & 4 & 0.54 & \\
\hline 2012 & $\begin{array}{l}\text { Gopalakrishnan } \\
\text { et al [62] }\end{array}$ & Nebraska & $\mathrm{M}$ & $\begin{array}{l}\text { Land not } \\
\text { capable of } \\
\text { agroeconomic } \\
\text { profitability } \\
\text { based on land } \\
\text { use, soil health } \\
\text { and } \\
\text { environmental } \\
\text { degradation }\end{array}$ & $\begin{array}{l}\text { Brownfield; } \\
\text { riparian, road and } \\
\text { impaired stream } \\
\text { buffers; } \\
\text { contaminated land }\end{array}$ & 0.85 & 15.64 & 5.31 & 4.25 & $\begin{array}{l}\text { Lower range } \\
\text { of estimates } \\
\text { used for } \\
\text { calculations }\end{array}$ \\
\hline 2012 & Fahd et al. [68] & Campania & $\mathrm{S}$ & $\begin{array}{l}\text { All non- } \\
\text { cultivated areas } \\
\text { where actual } \\
\text { primary } \\
\text { production is too } \\
\text { low to allow } \\
\text { competitive } \\
\text { agriculture }\end{array}$ & $\begin{array}{l}\text { Highly polluted } \\
\text { land suitable } \\
\text { neither for food } \\
\text { production nor for } \\
\text { biodiversity } \\
\text { development }\end{array}$ & 0.045 & 0.2 & 22.5 & 3.31 & \\
\hline 2012 & Liu et al. [59] & SW China & $\mathrm{L}$ & $\begin{array}{l}\text { Land that has } \\
\text { relatively poor } \\
\text { natural condition } \\
\text { but is able to } \\
\text { grow energy } \\
\text { plants, or land } \\
\text { that is not } \\
\text { currently in use } \\
\text { for agriculture } \\
\text { but is capable of } \\
\text { growing certain } \\
\text { plants }\end{array}$ & $\begin{array}{l}\text { Barren land } \\
\text { (shoal/bottomland, } \\
\text { saline and alkaline } \\
\text { land, and bare land) }\end{array}$ & 0.007 & 0.92 & 0.77 & 0.005 & \\
\hline
\end{tabular}




\begin{tabular}{|c|c|c|c|c|c|c|c|c|c|c|}
\hline 2012 & Lu et al. [58] & China & $\mathrm{L}$ & $\begin{array}{l}\text { Land unsuitable } \\
\text { for crop } \\
\text { production, but } \\
\text { ideal for growth } \\
\text { of energy plants } \\
\text { with high stress } \\
\text { resistance }\end{array}$ & $\begin{array}{l}\text { Unused land } \\
\text { (including alkaline } \\
\text { land, bare land and } \\
\text { shoal/bottomland) }\end{array}$ & 0.86 & 18.28 & 4.7 & 0.09 & \\
\hline 2013 & $\begin{array}{l}\text { Niblick et al. } \\
\text { [94] }\end{array}$ & Pittsburgh US & $\mathrm{S}$ & $\begin{array}{l}\text { Urban marginal } \\
\text { lands: lots with } \\
\text { poor agricultural } \\
\text { potential and } \\
\text { unfit for } \\
\text { residential } \\
\text { purposes }\end{array}$ & $\begin{array}{l}\text { Vacant lots; } \\
\text { surrounds of } \\
\text { developed lots; } \\
\text { special land uses: } \\
\text { strip mines, gullied } \\
\text { land, gravel pits, } \\
\text { quarries, coal } \\
\text { dump, industrial } \\
\text { dump }\end{array}$ & 0.002 & 0.002 & 100 & 16.7 & $\begin{array}{l}\text { Not clear what } \\
\text { proportion of } \\
2400 \text { ha } \\
\text { belongs to } \\
\text { specific land } \\
\text { types }\end{array}$ \\
\hline 2014 & $\begin{array}{l}\text { Milbrandt et al. } \\
\text { [53] }\end{array}$ & United States & $\mathrm{L}$ & $\begin{array}{l}\text { Lands with } \\
\text { inherent } \\
\text { disadvantages or } \\
\text { lands that have } \\
\text { been } \\
\text { marginalized by } \\
\text { natural and/ or } \\
\text { artificial forces }\end{array}$ & $\begin{array}{l}\text { Abandoned mine } \\
\text { lands; EPA sites } \\
\text { including } \\
\text { brownfield and } \\
\text { "Superfund" } \\
\text { sites; Rights-of- } \\
\text { Ways including } \\
\text { road, rail and } \\
\text { transmission line } \\
\text { buffers; barren land }\end{array}$ & 21.18 & 86.48 & 24.5 & 2.15 & $\begin{array}{l}\text { Excludes all } \\
\text { urban areas }\end{array}$ \\
\hline 2015 & $\begin{array}{l}\text { Saha and } \\
\text { Eckelman [65] }\end{array}$ & Boston & $\mathrm{S}$ & $\begin{array}{l}\text { Urban marginal } \\
\text { lands: land } \\
\text { parcels that have } \\
\text { limited } \\
\text { economic value } \\
\text { and are not } \\
\text { suitable for } \\
\text { agricultural } \\
\text { purposes }\end{array}$ & $\begin{array}{l}\text { Public/private } \\
\text { lands; residential/ } \\
\text { commercial } \\
\text { underutilised areas }\end{array}$ & 0.003 & 0.003 & 100 & 24 & $\begin{array}{l}\text { Not clear how } \\
\text { 'utilisation' is } \\
\text { measured i.e. } \\
\text { backyards } \\
\text { included }\end{array}$ \\
\hline 2015 & $\begin{array}{l}\text { Wang and Shi } \\
{[61]}\end{array}$ & $\begin{array}{l}\text { Guangdong } \\
\text { Province }\end{array}$ & $\mathrm{M}$ & $\begin{array}{l}\text { Land not } \\
\text { suitable for } \\
\text { growing field }\end{array}$ & $\begin{array}{l}\text { Shoal/bottomland } \\
\text { and unused land } \\
\text { (sand marsh, }\end{array}$ & $\begin{array}{l}\text { 'very small } \\
\text { proportion' }\end{array}$ & 2.5 & $\mathrm{n} / \mathrm{a}$ & $\mathrm{n} / \mathrm{a}$ & \\
\hline
\end{tabular}




\begin{tabular}{|c|c|c|c|c|c|c|c|c|c|c|}
\hline & & & & $\begin{array}{l}\text { crops due to } \\
\text { edaphic and/ or } \\
\text { climatic } \\
\text { limitations, } \\
\text { vulnerability to } \\
\text { erosion, or other } \\
\text { environmental } \\
\text { risks, but might } \\
\text { be usable for } \\
\text { growing crops }\end{array}$ & $\begin{array}{l}\text { marsh land, and } \\
\text { bare land) }\end{array}$ & & & & & \\
\hline 2016 & $\begin{array}{l}\text { Edrisi and } \\
\text { Abhilash [74] }\end{array}$ & India & $\mathrm{L}$ & $\begin{array}{l}\text { 'Potential } \\
\text { marginal land' is } \\
\text { defined as } \\
\text { wastelands, all } \\
\text { types of lands } \\
\text { degraded by } \\
\text { natural as well } \\
\text { as anthropogenic } \\
\text { activities, that } \\
\text { meet a range of } \\
\text { biophysical } \\
\text { considerations }\end{array}$ & $\begin{array}{l}\text { Mining/industrial } \\
\text { wastelands }\end{array}$ & 0.065 & 39.24 & 0.17 & 0.02 & \\
\hline 2016 & $\begin{array}{l}\text { Niblick and } \\
\text { Landis [93] }\end{array}$ & United States & $\mathrm{L}$ & $\begin{array}{l}\text { Land unfit for } \\
\text { food grade } \\
\text { agriculture and } \\
\text { not otherwise } \\
\text { fulfilling } \\
\text { conservation } \\
\text { purposes or } \\
\text { ecosystem } \\
\text { services }\end{array}$ & $\begin{array}{l}\text { Abandoned mine } \\
\text { lands; brownfield } \\
\text { land; closed landfill }\end{array}$ & 2.82 & 2.82 & 100 & 0.29 & \\
\hline 2016 & Xue et al [95] & China & $\mathrm{L}$ & $\begin{array}{l}\text { Land presently } \\
\text { not used for } \\
\text { agricultural } \\
\text { production, } \\
\text { residential } \\
\text { purposes, and } \\
\text { other social uses }\end{array}$ & $\begin{array}{l}\text { Shoal land; } \\
\text { bottomland; sand } \\
\text { land; alkaline land; } \\
\text { bare land }\end{array}$ & 79.39 & 171.64 & 46.2 & 8.27 & $\begin{array}{l}\text { 'Suitable' } \\
\text { marginal land } \\
\text { used for } \\
\text { calculations } \\
\text { rather than } \\
\text { 'available' } \\
\text { marginal land }\end{array}$ \\
\hline
\end{tabular}




\begin{tabular}{|c|c|c|c|c|c|c|c|c|c|c|}
\hline 2018 & $\begin{array}{l}\text { Saha and } \\
\text { Eckelman [67] }\end{array}$ & $\begin{array}{l}\text { MAPC } \\
\text { region, } \\
\text { Massachusetts }\end{array}$ & $\mathrm{S}$ & $\begin{array}{l}\text { Lands that are } \\
\text { not suitable for } \\
\text { food based } \\
\text { agriculture and } \\
\text { have limited } \\
\text { economic } \\
\text { potential for } \\
\text { fulfilling other } \\
\text { ecosystem } \\
\text { services }\end{array}$ & $\begin{array}{l}\text { Residential and } \\
\text { commercial } \\
\text { underutilised areas; } \\
\text { landfills; junkyards }\end{array}$ & $\begin{array}{l}0.053- \\
0.071\end{array}$ & 0.071 & 75 & 15 & $\begin{array}{l}\text { Not clear what } \\
\text { proportion is } \\
\text { abandoned } \\
\text { cropland of } \\
\text { final } 25 \% \\
\text { therefore } \\
\text { lower bound } \\
\text { used }\end{array}$ \\
\hline
\end{tabular}

*Scale: S (small) <10 Mha, M (medium) 10-100 Mha, L (large) > 100 Mha 
Fig. 3. Prevalence of marginal land areas comparing agricultural and non-agricultural types found in surveys at different scales (see Table 1). Open symbols denote studies including non-agricultural land types falling outside of our stricter definition.

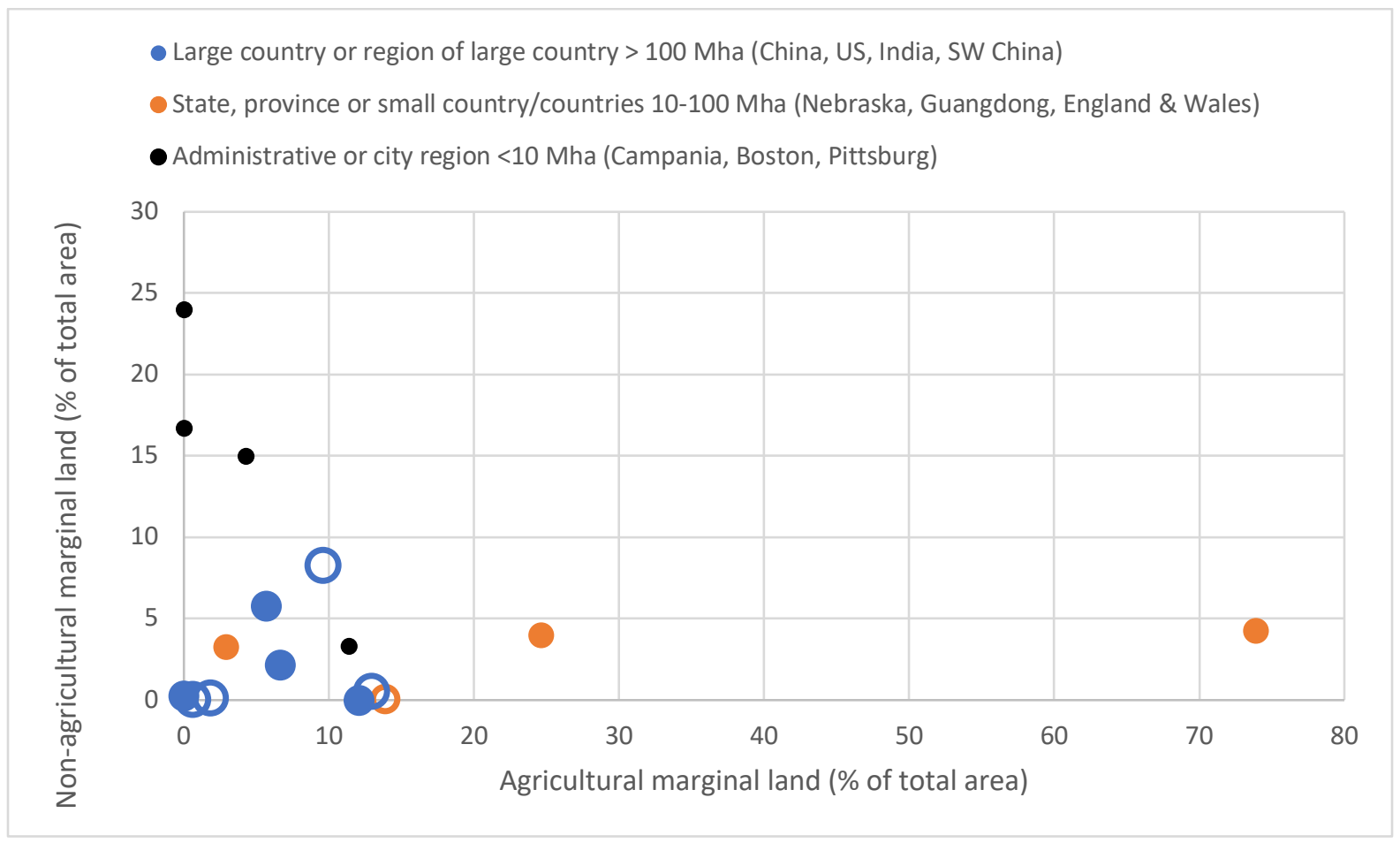

In many of the studies non-agricultural land types are areas impacted by previous human use, whether contaminated land [62], former mining land [74,94], brownfield land $[27,53,62,67,68,92,93]$ or landfill and dumps $[67,93,94]$. However, there is a stark lack of consistency as to which non-agricultural land types have been considered and, therefore, no standard methodology applied in order to identify these land categories.

The quantitative data for non-agricultural and agricultural marginal lands shown in Table 1 are summarized in Fig. 3. An extreme range of intensity of all marginal land is reported as a fraction of the total land area considered (0.3-78\%). If the outlier in the former is ignored then the range seen for the intensity of agricultural (0-25, then $74 \%)$ and non-agricultural $(0-24 \%)$ marginal land types is broadly similar. Within these ranges the proportion of marginal land area categorised as non-agricultural also varies widely $(0.017-100 \%)$. The three smallest scale, urban regional studies $[65,67,94]$ found the highest intensities of non-agricultural marginal land overall (15-24\%) with almost no agricultural land types - as is to be expected given the tendency for these to be outwith city limits. Surprisingly, the remaining larger scale studies showed that the intensity of non-agricultural marginal lands often still approached that of agricultural types. However, it must be noted that some of these previous studies [57-59,61,95] included various natural marginal land types as non-agricultural which would be classed as agricultural marginal lands in our revised definition (see Table 1). The latter were all in China and included various natural wastelands in the totals for non-agricultural marginal land as these are regionally important. These are shown as open symbols to denote this ambiguity and possible overallocation of non-productive marginal land areas to the non-agricultural rather than the agricultural land totals. 
The absence of conformity to a definition of marginal or the land categories that can be considered means that the actual areas of marginal land found and the relative contribution of agricultural and non-agricultural types should be treated with some degree of caution. What is clear from this critical review, however, is that consideration of non-agricultural lands types should not be overlooked when determining exactly what role marginal land could play with regards to bioenergy provision. Data was only available for all or part of three developed countries and two emerging economies. Clearly, more robust evidence is needed before any global policy decisions can be made to promote or discourage the use of this land type for bioenergy.

\subsection{Opportunities for renewables provided by non-agricultural land types}

This review has shown that overlooking non-agricultural land types is a critical omission in assessing marginal land resources, as this could risk ignoring up to half of the available land area at national scales, perhaps even more for urban regions. If the true potential of all marginal land for bioenergy is to be quantified then a better understanding of these land types is required, following an inclusive definition and exhaustive taxonomy with a clear analysis of any potential overlaps (Fig. 2). Each of the main non-agricultural marginal land types discussed in the literature is now considered in turn.

\subsubsection{Brownfields}

The definition of brownfield land varies globally, with a tendency in the United States to focus on the presence of contamination [96]. To distinguish it from other non-agricultural land resources that may be contaminated, the definition provided by Alker et al. [97] is that brownfield land is 'any land or premises which has previously been used or developed and is not currently fully in use, although it may be partially occupied or utilised. It may also be vacant, derelict, or contaminated' [97]. Brownfield lands are often considered eyesores or even potential health hazards [98]. The difficulty of redeveloping these sites, coupled with the increased requirement for renewable sources of energy have resulted in them being considered for renewable energy provision [98]. In terms of biomass production, brownfield land has been investigated as a potentially usable land resource in the North East of England with a scoping study of available non-agricultural land types [99,100]. The practicality of utilising this land type for bioenergy production has been evaluated by several further studies. Lord [43] describes the use of compost to establish energy crops on brownfield land, offering longer-term soil carbon benefits [45] and productivity within the range 4-10 dry t.ha ${ }^{-1} \mathrm{a}^{-1}$ postulated for uncultivated lands with "marginal potential" [11]. Furthermore, Smith et al. [101] compared the yield of bioenergy crops on a remediated site in the United States with a historically cropped agricultural site and found there to be little difference in yields, arguing that brownfield land has the potential to produce suitable quality feedstock.

Brownfield land has also been assessed in terms of the role it could play in providing other renewable energies. Adelaja et al. [98] investigated the wind and solar potential on brownfield sites in Michigan, concluding that utilisation of this resource could provide $43 \%$ of Michigan's residential electricity consumption. Similarly, the potential for brownfield redevelopment for solar energy purposes has also been investigated in the Czech Republic [102]. In the UK, Donaldson and Lord [103] have provided an assessment of the brownfield land availability in Glasgow City, arguing that these sites could be reused for ground source heating to help alleviate fuel poverty in the city. In the United States research regarding brownfield land for 
renewable energy provision is often undertaken alongside the consideration of other contaminated land types. Foremost of these attempts is the Environmental Protection Agency's 'RE-Powering America's Land' initiative, which sought to better understand the role formerly contaminated lands, landfills, and mine lands could play for renewable energy development [104]. This initiative includes brownfields as well as "Superfund" sites, sites contaminated by hazardous waste and identified by the EPA for clean-up as contaminated lands. Mosey et al. [105] investigated these 'limbo lands' on behalf of the EPA, creating a screening process to identify sites with a high potential for renewable energy technologies. More recently, Waite [106] undertook research regarding the potential for renewable energy installations on 81,000 sites associated with federal clean-up programs in US.

\subsubsection{Landfills}

Both Mosey et al. [105] and Waite [106] in America, and Evans [99] in the UK, have included landfill as an option for siting of renewable energy technologies. McKendry [107] has discussed the potential for restored landfill sites to provide biomass which could supplement landfill gas fuelled power stations. Furthermore, Ettala [108] studied tree plantations on six landfill sites in Finland, finding that short-rotation plantations can be established and the quality of the resulting biomass would allow it to be cultivated as a source of energy. The concept of using closed landfill for the provision of renewable energy has also been investigated in Hungary [109], with researchers declaring solar photovoltaic installations on former landfill sites a 'win-win'. According to their findings the establishment of solar PV systems can simultaneously avoid the environmental, economic and land value concerns of post landfill closure whilst providing renewable energy.

\subsubsection{Mine lands}

Another land type also considered by the EPA Re-Powering America initiative [104] is abandoned mine land. In reference to the EPA initiative, Buchsbaum [110] argues that abandoned mines and the area immediately surrounding them are not usually considered for reuse due to safety and environmental concerns, yet there have been examples of them being utilised for cleaner sources of energy in countries such as Germany [110]. This has also been discussed elsewhere, with Rocio [111] even suggesting that an abandoned mercury mine could be cropped. A Waste \& Resources Action Programme (WRAP) project identified the potential for biofuel crop production on a restored former coal washing site in Kinglassie, Scotland [112]. Old mineral workings have also been considered in terms of their potential for siting bioenergy projects [113], with Dubuc [113] identifying clusters of quarries that be used for energy crops to satisfy nearby power plant demand.

\subsubsection{Contaminated, remediated and restored land}

There is the potential for soil contamination to be present in brownfields, landfills and mine lands. Surveys indicate the existence of 2.8 million potentially contaminated sites, just across the EU-28. While 650,000 sites have been registered, only 1 in 10 have so far been remediated [114]. The main activities responsible are waste disposal \& treatment, followed by industrial \& commercial activities, while the main types of contaminants are potentially toxic elements (including heavy metals) at roughly a third of sites, followed by petroleum at nearly a quarter [115]. Together with poly-aromatic hydrocarbons, other aromatic hydrocarbons and chlorinated hydrocarbons, organic compounds together account for over $50 \%$ of all 
contamination. The management of EU contaminated sites is estimated at $€ 6$ billion annually [116]. The extent of land area affected by contamination is more difficult to define or quantify. Agricultural lands may also be contaminated naturally, from industrial pollution or after agricultural spreading. For example, a 2014 Government study in China found $16.1 \%$ of all soil and $19.4 \%$ of arable land showed contamination, with $\mathrm{Cd}, \mathrm{Ni}$ and As the main pollutants [117].

To acknowledge their potential distribution, contaminated lands are shown spanning both agricultural and non-agricultural marginal lands (Fig. 2). It is now well established by successful demonstrations that remediated and restored sites may offer an opportunity for biomass production, whether these were originally brownfields [100,118], landfills [101,119] or mining sites [120,121]. A number of studies suggest that combining phytoremediation with energy crops is a "win-win" opportunity [18,122-124]. Here remediation is the remedying of issues such as soil contamination or dereliction, whereas restoration refers to reinstatement of land, especially after mining or quarrying excavation or landfilling of waste deposits. These generalisations are reflected in the complex overlapping fields shown for these inter-related types of non-agricultural marginal land.

\subsubsection{Buffers, utility \& urban lands}

Riparian buffers were included in the assessment of marginal land undertaken by Gopalakrishnan et al. [27,62]. Areas surrounding waterways have been investigated by Fortier et al. [125] who assessed the potential to produce biomass on deforested farm streams in 3 watersheds. Various unconventional urban sources of non-agricultural land have been considered for renewable energy technology establishment [126]. Arodudu et al. [126] employed a GIS methodology to identify and estimate the bioenergy potential from green roofs and construction sites which the authors argue could be used in addition to domestic organic waste and leaf-fall collection from recreational parks. Van Meerbeek et al. [127] also suggest that residues could be collected from a range of non-agricultural 'landscape biomass' sources such as sports fields, parks, roadsides and conservation areas.

\subsection{Challenges to identify or classify non-agricultural lands}

A common theme and limitation raised across these studies again is the quality of data and consequently poor methodologies employed. Oliver [96] outlines the requirement for more data regarding brownfield in Europe to enable successful monitoring of flows in this resource. The presence of incomplete or missing data has also been highlighted [102]. This requirement potentially undermines the validity of these studies as a representation of the land resource that exists. Mosey et al. [105] considered the provision of 'limbo lands', including landfill, "Superfund", abandoned mine land, brownfield and former industrial sites, and yet the analysis only utilises data from the National Priorities List of sites 'threatening releases of hazardous substances, pollutant or contaminants' [105]. Likewise, Waite [106] is limited to the sites that had been screened by the EPA's initiative, and the author admits that only eleven states provided further data. Additionally, the studies that implement a GIS approach to identify brownfield land, such as Niblick and Landis [93], have represented the land parcels as points, yet if any judgement is to be made about their suitability for siting renewable technology further detail on their layout would be required. One attempt to create a more detailed picture of the collective non-agricultural land resource, is the investigation undertaken in North West 
England as part of the Newlands Project (New Environments via Woodlands) [128][129][130]. This implemented a bottom-up approach based on aerial imagery and desk studies to identifying any derelict, underused and neglected land parcels, then consulted local authorities regarding the identified sites and evaluated end-use suitability while recording potential socioeconomic benefits. Future attempts to identify the non-agricultural land resource for renewable energy provision could consider adopting elements of this methodology to gain a better picture of the collective land resource and cost-benefit analysis.

\subsection{Using non-agricultural land types - Benefits}

Considering non-agricultural land separately from other marginal land allows the unique benefits of using these land types to be fully captured. Spiess and De Sousa [131] summarise the advantages of siting renewable energy technology on brownfield land as 'triple bottom-line benefits', with environmental, social and economic gains. The most notable of the triad of benefits is the reduced environmental impact of using these land types, either for bioenergy or other renewable technologies. Most relevant is the unique opportunity that using land types such as brownfield land could provide in producing carbon neutral biomass without impacting on food production [132].

It has been argued that implementation of bioenergy could bring a range of further environmental benefits such as ecological improvement [132], blight removal [98], and helping to rebuild the soil profile on land that is often of poor quality [42]. Blanco-Canqui [42] has even suggested that growing dedicated energy crops on reclaimed mine soils can have a higher potential to sequester soil carbon in the first 20-25 years following reclamation than on agricultural land. Lord and Sakrabani have shown that significant soil carbon increases extend beyond 10 years when compost is used to establish perennial energy crops on brownfields [45].

As has already been suggested a further benefit from bioenergy production on contaminated lands is the role these energy crops could play in remediating the sites [18,132]. Phytoremediation is the use of plants to destroy, extract, stabilize or contain contaminants [18], and has been promoted as a cost effective in situ remediation option [42] that avoids the need for energy intensive process-based remediation or extraction [132]. Phytoremediation has also been encouraged, despite being a slower form of remediation [133], due to the additional environmental advantages of erosion control, reduced greenhouse gas emissions and waste generation, and increasing the biodiversity on sites [18], whilst simultaneously generating revenue from the biomass sold [134]. Many contaminated sites currently have a negative asset value due to the anticipated costs of future remediation or maintenance [132] which could be side-stepped if the site is put into use for bioenergy provision. Alternatively, other sites are not contaminated enough to trigger regulatory remediation options and therefore sit idle and derelict [18], which could be avoided if these sites were considered as a source of bioenergy. In the case of landfills, phyto-capping, the placing of a layer of soil material atop the landfill and growing of a dense layer of vegetation, has been deemed to enhance aesthetic qualities and introduce economic benefits if energy can be generated [135]. Lamb et al. [136] describe how phyto-capping can also mitigate the environmental impact of leachate generation and GHG emissions. Finally, a further set of unique environmental benefits have been claimed if renewable energy technologies target the urban non-agricultural land resource - including the role that biomass could play in urban flood prevention, reducing the urban heat island effect [126] and delivering other ecosystem services [42]. 
It has also been argued that there are economic benefits to be gained from using nonagricultural land for bioenergy provision [120]. One such economic benefit, which can be extended to other land-based renewables, is that reusing these non-agricultural land types may be more cost effective as they already have road connections, and often also have fencing and are connected to the grid [109,131]. Furthermore, Donaldson and Lord [103] argue that brownfield land can provide low cost energy to target fuel poverty, identifying a tendency for these sites to be in close proximity to social housing in urban areas. It has also been claimed that targeting brownfield land for bioenergy can lead to the creation of jobs and investments in often run-down post-industrial landscapes $[98,131]$.

Utilisation of non-agricultural land types can give other positive social impacts. Using sites for bioenergy provision, for instance, has been linked to community redevelopment benefits [98,132] and aesthetic improvement [120]. Bambra et al. [137] have called for brownfield land to be considered an element of environmental deprivation, highlighting the link between brownfield land and spatial inequalities in health, including morbidity. This research concludes that people living in wards with a higher proportion of brownfield land are significantly more likely to suffer from poorer health than those living in wards with less [137]. The paper not only links contaminated brownfield with potential risks to physical health via the 'sourcepathway-receptor' model, but also argues that brownfield land is an 'untherapeutic landscape' [137] and a marker of long term industrial decline and 'spoiled identity' [137]. The authors contrast the state of brownfields with the notion of biophilia, arguing that humans prefer natural settings due to an inherent association with resources and protection [138]. From this perspective, the greening or remediation of brownfield or other non-agricultural land types could be considered to have wider societal benefits and could potentially be linked to an improvement in community health.

\subsection{Using non-agricultural land types - Challenges}

The most prominent issue for the use non-agricultural land types for renewable energy deployment, particularly bioenergy, is the quality of the land. Lord et al. [132] outline several challenges that may face attempts to grow biomass on these land resources including shallow soil depth, compaction and low water retention, limited nutrients, low organic matter and potential phytotoxicity [43]. Additional issues arise due to competition on these sites from weeds and pests, and the existence of structural remains and made-ground [43]. The quality of the land can have a direct impact on the ability to grow biomass productively on these sites and Blanco-Canqui [42] concludes that a lower yield is to be expected compared with prime agricultural land. Spiess and De Sousa [131] consider that the main difference between renewable energy developments on brownfield land and other sites, is in the potential for contamination, eclipsing the various other technical, environmental, financial, regulatory, industrial, and social barriers discussed below. Donaldson and Lord [103] reiterate this point, emphasizing that the additional costs associated with remediation need to be considered if nonagricultural land types are to be utilised for renewable energy technologies.

In common with all marginal lands, primary productivity will be controlled by other biophysical factors, including insolation, rainfall and climate, which may be severely reduced in less desirable agricultural areas [11], or by environmental restrictions for unused areas of higher productivity land, such as the requirements of the EU Renewable Energy Directive's sustainability criteria $[139,140]$. Furthermore, any theoretical land area or bioenergy resource 
will be substantially reduced when realistic availability, technical or economic factors are considered [141,142].

Besides the challenges associated with land quality further complications can arise due to the high proportion of these land types within, or close to, urban areas [67]. The urban setting can lead to access and logistical problems or potential developers being faced with high land prices and labour costs [67]. The siting of renewable energy technologies can also lead to neighbourhood concerns [67] and an element of NIMBYism [131].

According to Saha and Eckelman [67] a further barrier to deployment of renewables in urban areas, is the competition for use of the land with other economic activities. This is not unique to urban areas as there is a wide spectrum of potential end uses for non-agricultural land resources that are currently left idle or underutilised. Current work has focused on the wider benefits, other than via development, of urban brownfield land [143], which has the greatest competition for use, given the barriers to using land types such as closed landfill and abandoned mine land. Of these, their potential use for ecological restoration is most common [143-145]. There has been an increased awareness of the importance of previously developed land for wildlife [145] and biodiversity conservation [144]. Macadam and Bairner [145] argue that brownfield sites can support many rare, scarce and UK Biodiversity Action Plan [146] priority species. Similarly, Plieninger and Gaertner [144] have suggested that degraded lands may support biodiversity levels similar to or above those of managed landscapes and are therefore an untapped resource for conservation [144]. They argue that use of these lands for bioenergy may generate difficult trade-offs with ecosystem functions and conservation of biodiversity, even claiming that energy crops exhibit 'traits of invasive weeds' [144]. It has been suggested that these non-agricultural land types, such as brownfield land, would be better utilised as a source of greenspace, including wildflower meadows [147] or forestry [148]. Mathey et al. [149] has proposed that brownfield land in urban settings would be ideal for greenspace provision with the additional benefits of microclimate regulation and new recreational space development. In contrast, it has also been suggested that brownfield land could play an important role in housing provision [150]. A report produced by the Campaign to Protect Rural England, concluded that up to 1.1 Million homes could be built in England on brownfield land, with enough land to meet 5-year house land supply targets [150]. In summary, competing uses could be a barrier for the implementation of bioenergy developments, or other renewable technologies on the land, highlighting the requirement for detailed, usable information on this land resource to guide future decision making.

\subsection{Implications for future work}

To improve future estimates of the specific contribution that different non-agricultural or marginal land types could make to renewable energy provision, better quality site data and a more consistent identification methodology are needed. A consistent and inclusive definition and classification scheme, such as those proposed here (Fig. 2), are prerequisites for consistent identification, accurate classification and quantification of the resultant bioenergy potential. Any future attempts should consider taking a bottom-up approach [30] in order to gain a more detailed understanding of their spatial properties and distribution. A more detailed representation of these land resources will ultimately enable a more accurate assessment to ensure that land can be mobilized for the most appropriate end usage, whether that be as a source of sustainable bioenergy, or for an alternative competing use, such as greenspace or 
housing provision. Furthermore, a combination of a detailed understanding of the nonagricultural land resources that is available for second generation biomass crops could be combined with other relevant datasets, such as the availability of non-conventional urban sources of biomass [126] or the residue that could be accrued from landscape biomass [127], so as to provide a unique national assessment of the provision of bioenergy that could be achieved without impacting on agricultural production. Critical selection criteria for implementation will be the unsuitability, unacceptability or unavailability of these sites for future food production, coupled with adequate biophysical conditions for socio-economically viable production, while still meeting acceptable environmental and other sustainability criteria, including the UN Sustainable Development Goals [151].

\section{Conclusion}

This paper has clearly demonstrated that there are many remaining issues with the potential of marginal land to support sustainable biofuel production. The current discourse is dominated by discussion of the role that such alternative land resources could play if not in use for food production. This qualitative review has highlighted several recurring problems. Critically, the ambiguity in previous definitions of marginal land and the associated lack of any consistent identification methodology reduces the level of confidence that can be attached to any subsequent results. Furthermore, the temporality of the economic definition often employed leads to concerns regarding the longevity or sustainability of the land identified as being marginal or whether it might be needed for future food production. The new definition proposed directly addresses this temporality issue and encompasses a wider range of nonagricultural sites manifestly unsuitable for food production, illustrated in a comprehensive schematic diagram (Fig. 2).

Quantitative evaluation of the literature has highlighted the variable inclusion of nonagricultural land types within marginal land resource assessments. The past studies are compromised by inconsistent definitions, methodologies and inclusion of different nonagricultural land categories. However, non-agricultural marginal lands can be as much as a quarter of the land area considered and may contribute up to half of the total identified marginal land areas, even at country scale.

Acknowledgements: This work was supported by University of Strathclyde Faculty of Engineering, the Department of Civil \& Environmental Engineering, and originally by Parsons Brinckerhoff (now WSP). We thank the anonymous reviewers who greatly helped to improve the revised manuscript.

\section{List of references}

[1] Sims REH. Renewable energy: A response to climate change. Sol Energy 2004;76:9-17. doi:10.1016/S0038-092X(03)00101-4.

[2] DEFRA. Energy White Paper: Our energy future - creating a low carbon economy. London: 2003.

[3] REN21. Renewables 2017: global status report. vol. 72. Paris: 2017. doi:10.1016/j.rser.2016.09.082.

[4] Foster E, Contestabile M, Blazquez J, Manzano B, Workman M, Shah N. The unstudied barriers to widespread renewable energy deployment: Fossil fuel price responses. Energy Policy 2017;103:258-64. doi:10.1016/j.enpol.2016.12.050.

[5] Welfle A, Gilbert P, Thornley P. Securing a bioenergy future without imports. Energy Policy 2014;68:1-14. doi:10.1016/j.enpol.2013.11.079. 
[6] Dale VH, Kline KL, Wright LL, Perlack RD, Downing M, Graham RL. Interactions among bioenergy feedstock choices, landscape dynamics, and land use. Ecol Appl 2011;21:1039-54. doi:10.1890/090501.1

[7] Gallagher E. The Gallagher review of the indirect effects of biofuels production. St Leonards-on-Sea, East Sussex: 2008. doi:10.1111/j.2008.0908-8857.04218.x.

[8] Das PK, Das BP, Dash P. Role of Energy Crops to Meet the Rural Energy Needs: An Overview. In: Praveen Kumar R, Bharathiraja B, Kataki R, Moholkar VS, editors. Biomass Valorization to Bioenergy, Singapore: Springer Singapore; 2020, p. 11-30. doi:10.1007/978-981-15-0410-5_2.

[9] World Energy Council. World Energy Resources Bioenergy 2016. 2016. doi:10.1016/0165232X(80)90063-4.

[10] Wicke B. Bioenergy production on degraded and marginal land: Assessing its potentials, economic performance, and environmental impacts for different settings and geographical scales. Utrecht University, 2011.

[11] Schueler V, Fuss S, Steckel JC, Weddige U, Beringer T. Productivity ranges of sustainable biomass potentials from non-agricultural land. Environ Res Lett 2016;11:074026. doi:10.1088/17489326/11/7/074026

[12] Bauen A, Berndes G, Junginger M, Vuille F, Londo M. Bioenergy - A Sustainable and Reliable Energy Source. Didcot, Oxfordshire: 2009. doi:ExCo: 2009:06.

[13] Langholtz M, Stokes B, Eaton L. 2016 billion-ton report: Advancing domestic resources for a thriving bioeconomy (Executive Summary). vol. 1. 2016. doi:10.1089/ind.2016.29051.doe.

[14] Turner PA, Mach KJ, Lobell DB, Benson SM, Baik E, Sanchez DL, et al. The global overlap of bioenergy and carbon sequestration potential. Clim Change 2018;148:1-10. doi:10.1007/s10584-0182189-z.

[15] Bosch R, Van De Pol M, Philp J. Policy: Define biomass sustainability. Nature 2015;523:526-7. doi:10.1038/523526a.

[16] Lewandowski I. Securing a sustainable biomass supply in a growing bioeconomy. Glob Food Sec 2015;6:34-42. doi:10.1016/j.gfs.2015.10.001.

[17] European Commission. Biomass n.d. https://ec.europa.eu/energy/topics/propertyfieldtopicparent/biomass_en\#sustainable-biomass.

[18] Andersson-Sköld Y, Hagelqvist A, Crutu G, Blom S. Bioenergy grown on contaminated land - A sustainable bioenergy contributor? Biofuels 2015;5:487-98. doi:10.1080/17597269.2014.996728.

[19] Howard DC, Burgess PJ, Butler SJ, Carver SJ, Cockerill T, Coleby AM, et al. Energyscapes: Linking the energy system and ecosystem services in real landscapes. Biomass and Bioenergy 2013;55. doi:10.1016/j.biombioe.2012.05.025.

[20] DECC. The Future of Heating: Meeting the challenge. London: 2013.

[21] Dale VH, Kline KL, Wiens J, Fargione J. Biofuels: Implications for Land Use and Biodiversity. Biofuels Sustain Reports 2010:13.

[22] Fargione J, Hill J, Tilman D, Polasky S, Hawthorne P. Land clearing and the biofuel carbon debt. Science (80- ) 2008;319:1235-8. doi:10.1126/science.1152747.

[23] Lovett A, Sünnenberg G, Richter GM, Dailey a. G, Riche AB, Karp A. Land use implications of increased biomass production identified by gis-based suitability and yield mapping for miscanthus in england. Bioenergy Res 2009;2:17-28. doi:10.1007/s12155-008-9030-x.

[24] Coleby AM, van der Horst D, Hubacek K, Goodier C, Burgess PJ, Graves A, et al. Environmental Impact Assessment, ecosystems services and the case of energy crops in England. J Environ Plan Manag 2012;55:369-85. doi:10.1080/09640568.2011.603958.

[25] Tilman D, Socolow R, Foley JA, Hill J, Larson E, Lynd L, et al. Beneficial biofuels - The food, energy, and environment trilemma. Science (80- ) 2009;325:270-1. doi:10.1126/science.1177970. 
[26] Searchinger T, Heimlich R, Houghton RA, Dong F, Elobeid A, Fabiosa J, et al. Use of U.S. croplands for biofuels increases greenhouse gases through emissions from land-use change. Science (80- ) 2008;319:1238-40. doi:10.1126/science.1151861.

[27] Gopalakrishnan G, Negri MC, Wang M, Wu M, Snyder SW, Lafreniere L. Biofuels, land, and water: A systems approach to sustainability. Environ Sci Technol 2009;43:6094-100. doi:10.1021/es900801u.

[28] Lewis S, Kelly M. Mapping the Potential for Biofuel Production on Marginal Lands: Differences in Definitions, Data and Models across Scales. ISPRS Int J Geo-Information 2014;3:430-59. doi:10.3390/ijgi3020430.

[29] Wiegmann K, Hennenberg KJ, Fritsche UR. Degraded Land and Sustainable Bioenergy Feedstock Production. Jt Int Work High Nat Value Criteria Potential Sustain Use Degrad Lands, ParisOeko-Institut 2008;49:1-10.

[30] Mellor P. Evaluating the opportunity that could be provided by underutilised non-agricultural land as a source of bioenergy. University of Strathclyde, 2019.

[31] Smit B, Bray J, Keddie P. Identification of marginal agricultural areas in Ontario, Canada. Geoforum 1991;22:333-46. doi:10.1016/0016-7185(91)90016-J.

[32] Kang S, Post W, Nichols J, Wang D, West T, Bandaru V, et al. Marginal Lands : Concept, Assessment and Management. J Agric Sci 2013;5:129-39. doi:10.5539/jas.v5n5p129.

[33] Ricardo D. On the Principles of Political Economy and Taxation. Third. London: J.M. Dent \& Sons, ltd; 1817. doi:10.2307/2593726.

[34] Peterson GM, Galbraith JK. The concept of marginal land. Agric Appl Econ Assoc 1932;14:295-310.

[35] Strijker D. Marginal lands in Europe - Causes of decline. Basic Appl Ecol 2005;6:99-106. doi:10.1016/j.baae.2005.01.001.

[36] Schroers JO. Towards the development of marginal land use depending on the framework of agricultural market, policy and production techniques. University of Giessen, Germany: 2006.

[37] Soil resources development and conservation service land and water development division. A framework for land evaluation. Rome: Food and Agriculture Organization of the United Nations; 1976.

[38] Consultative Group on International Agricultural Research. CGIAR Research Priorities for Marginal Lands. 2000.

[39] Elbersen, B.; van Eupen, E.; Mantel, S.; Verzandvoort, S.; Boogaard, H.; Mucher, S.; Cicarreli, T.; Elbersen, W.; Bai, Z.; Iqbal, Y.; von Cossel, M.; McCallum, I.; Carrasco, J.; Ciria Ramos, C.; Monti, A.; Scordia, D.; Eleftheriadis I. D2.1. Definition and classification of marginal lands suitable for industrial crops in Europe. n.d. doi:10.5281/zenodo.3539229.

[40] Dauber J, Brown C, Fernando AL, Finnan J, Krasuska E, Ponitka J, et al. Bioenergy from surplus land: Environmental and socio-economic implications. BioRisk 2012;50:5-50. doi:10.3897/biorisk.7.3036.

[41] SEEMLA. What are 'marginal lands' (MagL)? 2016.

[42] Blanco-Canqui H. Growing Dedicated Energy Crops on Marginal Lands and Ecosystem Services. Soil Sci Soc Am J 2016;80:845. doi:10.2136/sssaj2016.03.0080.

[43] Lord RA. Reed canarygrass (Phalaris arundinacea) outperforms Miscanthus or willow on marginal soils, brownfield and non-agricultural sites for local, sustainable energy crop production. Biomass and Bioenergy 2015;78:110-25. doi:10.1016/j.biombioe.2015.04.015.

[44] Mensah F, Schoenau JJ, Malhi SS. Soil carbon changes in cultivated and excavated land converted to grasses in east-central Saskatchewan. Biogeochemistry 2003;63:85-92. doi:10.1023/A:1023369500529.

[45] Lord R, Sakrabani R. Ten-year legacy of organic carbon in non-agricultural (brownfield) soils restored using green waste compost exceeds 4 per mille per annum: Benefits and trade-offs of a circular economy approach. Sci Total Environ 2019. doi:10.1016/j.scitotenv.2019.05.174.

[46] Tang Y, Xie J-S, Geng S. Marginal Land-based Biomass Energy Production in China. J Integr Plant 
Biol 2010;52:112-21. doi:10.1111/j.1744-7909.2010.00903.x.

[47] Dauber J, Miyake S. To integrate or to segregate food crop and energy crop cultivation at the landscape scale? Perspectives on biodiversity conservation in agriculture in Europe. Energy Sustain Soc 2016;6. doi:10.1186/s13705-016-0089-5.

[48] Cervelli E, Scotto di Perta E, Pindozzi S. Energy crops in marginal areas: Scenario-based assessment through ecosystem services, as support to sustainable development. Ecol Indic 2020;113:106180. doi:10.1016/j.ecolind.2020.106180.

[49] Campbell JE, Lobell DB, Genova RC, Field CB. The global potential of bioenergy on abandoned agriculture lands. Environ Sci Technol 2008;42:5791-4. doi:10.1021/es800052w.

[50] Field CB, Campbell JE, Lobell DB. Biomass energy: the scale of the potential resource. Trends Ecol Evol 2008;23:65-72. doi:10.1016/j.tree.2007.12.001.

[51] Cai X, Zhang X, Wang D. Land Availability Analysis for Biofuel Production. Environ Sci Technol 2011;45:334-9. doi:10.1021/es103338e.

[52] Nijsen M, Smeets E, Stehfest E, van Vuuren DP. An evaluation of the global potential of bioenergy production on degraded lands. GCB Bioenergy 2012;4:130-47. doi:10.1111/j.1757-1707.2011.01121.x.

[53] Milbrandt A, Heimiller DM, Perry AD, Field CB. Renewable energy potential on marginal lands in the United States. Renew Sustain Energy Rev 2014;29:473-81. doi:10.1016/j.rser.2013.08.079.

[54] Odeh IO a, Tan DKY, Ancev T. Potential Suitability and Viability of Selected Biodiesel Crops in Australian Marginal Agricultural Lands Under Current and Future Climates. Bioenergy Res 2011;4:165-79. doi:10.1007/s12155-010-9110-6.

[55] Wu WG, Huang JK, Deng XZ. Potential land for plantation of Jatropha curcas as feedstocks for biodiesel in China. Sci China Earth Sci 2010;53:120-7. doi:10.1007/s11430-009-0204-y.

[56] Schweers W, Bai Z, Campbell E, Hennenberg K, Fritsche U, Mang HP, et al. Identification of potential areas for biomass production in China: Discussion of a recent approach and future challenges. Biomass and Bioenergy 2011;35:2268-79. doi:10.1016/j.biombioe.2011.02.034.

[57] Zhuang D, Jiang D, Liu L, Huang Y. Assessment of bioenergy potential on marginal land in China. Renew Sustain Energy Rev 2011;15:1050-6. doi:10.1016/j.rser.2010.11.041.

[58] Lu L, Jiang D, Zhuang D, Huang Y. Evaluating the marginal land resources suitable for developing Pistacia chinensis-based biodiesel in China. Energies 2012;5:2165-77. doi:10.3390/en5072165.

[59] Liu L, Zhuang D, Jiang D, Huang Y. Assessing the potential of the cultivation area and greenhouse gas (GHG) emission reduction of cassava- based fuel ethanol on marginal land in Southwest China. African J Agric Res 2012;7:5594-603. doi:10.5897/AJAR12.1387.

[60] Liu T, Ma Z, McConkey B, Kulshreshtha S, Huffman T, Green M, et al. Bioenergy production potential on marginal land in Canada. 2011 1st Int Conf Agro-Geoinformatics, Agro-Geoinformatics 2012 2011:660-3. doi:10.1109/Agro-Geoinformatics.2012.6311729.

[61] Wang F, Shi X. Geospatial analysis for utilizing the marginal land in regional biofuel industry: A case study in Guangdong Province, China. Biomass and Bioenergy 2015;83:302-10. doi:10.1016/j.biombioe.2015.10.005.

[62] Gopalakrishnan G, Negri M, Snyder SW. A novel framework to classify marginal land for sustainable biomass feedstock production. J Environ Qual 2011;40:1593-600. doi:10.2134/jeq2010.0539.

[63] Kang S, Post W, Wang D, Nichols J, Bandaru V, West T. Hierarchical marginal land assessment for land use planning. Land Use Policy 2013;30:106-13. doi:10.1016/j.landusepol.2012.03.002.

[64] Gelfand I, Sahajpal R, Zhang X, Izaurralde RC, Gross KL, Robertson GP. Sustainable bioenergy production from marginal lands in the US Midwest. Nature 2013;493:514-7. doi:10.1038/nature11811.

[65] Saha M, Eckelman MJ. Geospatial assessment of potential bioenergy crop production on urban marginal land. Appl Energy 2015;159:540-7. doi:10.1016/j.apenergy.2015.09.021. 
[66] Stoof CR, Richards BK, Woodbury PB, Fabio ES, Brumbach AR, Cherney J, et al. Untapped Potential: Opportunities and Challenges for Sustainable Bioenergy Production from Marginal Lands in the Northeast USA. Bioenergy Res 2015;8:482-501. doi:10.1007/s12155-014-9515-8.

[67] Saha M, Eckelman MJ. Geospatial assessment of regional scale bioenergy production potential on marginal and degraded land. Resour Conserv Recycl 2018;128:90-7. doi:10.1016/j.resconrec.2017.09.008.

[68] Fahd S, Fiorentino G, Mellino S, Ulgiati S. Cropping bioenergy and biomaterials in marginal land: The added value of the biorefinery concept. Energy 2012;37:79-93. doi:10.1016/j.energy.2011.08.023.

[69] Fiorese G, Guariso G. A GIS-based approach to evaluate biomass potential from energy crops at regional scale. Environ Model Softw 2010;25:702-11. doi:10.1016/j.envsoft.2009.11.008.

[70] Tenerelli P, Carver S. Multi-criteria, multi-objective and uncertainty analysis for agro-energy spatial modelling. Appl Geogr 2012;32:724-36. doi:10.1016/j.apgeog.2011.08.013.

[71] Milbrandt A, Overend R. Assessment of biomass resources from marginal lands in APEC economies. 2009. doi:10.2172/968464.

[72] Wicke B, Smeets E, Watson H, Faaij A. The current bioenergy production potential of semi-arid and arid regions in sub-Saharan Africa. Biomass and Bioenergy 2011;35:2773-86. doi:10.1016/j.biombioe.2011.03.010.

[73] Sudha P, Ravindranath NH. Land availability and biomass production potential in India. Biomass and Bioenergy 1999;16:207-21. doi:10.1016/S0961-9534(98)00083-X.

[74] Edrisi SA, Abhilash PC. Exploring marginal and degraded lands for biomass and bioenergy production: An Indian scenario. Renew Sustain Energy Rev 2016;54:1537-51. doi:10.1016/j.rser.2015.10.050.

[75] Shortall OK. Marginal land for energy crops: Exploring definitions and embedded assumptions. Energy Policy 2013;62:19-27. doi:10.1016/j.enpol.2013.07.048.

[76] Pulighe G, Bonati G, Colangeli M, Morese MM, Traverso L, Lupia F, et al. Ongoing and emerging issues for sustainable bioenergy production on marginal lands in the Mediterranean regions. Renew Sustain Energy Rev 2019;103:58-70. doi:10.1016/j.rser.2018.12.043.

[77] Shortall OK, Anker HT, Sandøe P, Gamborg C. Room at the margins for energy-crops? A qualitative analysis of stakeholder views on the use of marginal land for biomass production in Denmark. Biomass and Bioenergy 2019;123:51-8. doi:10.1016/j.biombioe.2019.01.042.

[78] Glithero NJ, Wilson P, Ramsden SJ. Optimal combinable and dedicated energy crop scenarios for marginal land. Appl Energy 2015;147:82-91. doi:10.1016/j.apenergy.2015.01.119.

[79] Haughton AJ, Bond AJ, Lovett A, Dockerty T, Sunnenberg G, Clark SJ, et al. A novel, integrated approach to assessing social, economic and environmental implications of changing rural land-use: A case study of perennial biomass crops. J Appl Ecol 2009;46:315-22. doi:10.1111/j.13652664.2009.01623.x.

[80] Helliwell R. Where did the marginal land go? Farmers perspectives on marginal land and its implications for adoption of dedicated energy crops. Energy Policy 2018;117:166-72. doi:10.1016/j.enpol.2018.03.011.

[81] Li H, Wu Y, Huang X, Sloan M, Skitmore M. Spatial-temporal evolution and classification of marginalization of cultivated land in the process of urbanization. Habitat Int 2017;61:1-8. doi:10.1016/j.habitatint.2017.01.001.

[82] Jiang W, Jacobson MG, Langholtz MH. A sustainability framework for assessing studies about marginal lands for planting perennial energy crops. Biofuels, Bioprod Biorefining 2019;13:228-40. doi:10.1002/bbb.1948.

[83] Lal R. Ten tenets of sustainable soil management. J Soil Water Conserv 2009;64:20A.

[84] Fischer G, Prieler S, Van Velthuizen H, Lensink SM, Londo M, De Wit M. Biofuel production potentials in Europe: Sustainable use of cultivated land and pastures. Part I: Land productivity potentials. Biomass and Bioenergy 2010;34:159-72. doi:10.1016/j.biombioe.2009.07.008. 
[85] Agriculture Act 1947, Part V, Section 109 1947. http://www.legislation.gov.uk/ukpga/Geo6/1011/48/section/109.

[86] Nilsson D, Rosenqvist H, Bernesson S. Profitability of the production of energy grasses on marginal agricultural land in Sweden. Biomass and Bioenergy 2015;83:159-68. doi:10.1016/j.biombioe.2015.09.007.

[87] Sallustio L, Pettenella D, Merlini P, Romano R, Salvati L, Marchetti M, et al. Assessing the economic marginality of agricultural lands in Italy to support land use planning. Land Use Policy 2018;76:526-34. doi:10.1016/j.landusepol.2018.02.033.

[88] Swinton SM, Babcock B a., James LK, Bandaru V. Higher US crop prices trigger little area expansion so marginal land for biofuel crops is limited. Energy Policy 2011;39:5254-8. doi:10.1016/j.enpol.2011.05.039.

[89] Jiang D, Wang Q, Ding F, Fu J, Hao M. Potential marginal land resources of cassava worldwide: A data-driven analysis. Renew Sustain Energy Rev 2019;104:167-73. doi:10.1016/j.rser.2019.01.024.

[90] Stocking MA. Land degradation. Int Encycl Soc Behav Sci 2001:8242-7.

[91] Kukk L, Astover A, Muiste P, Noormets M, Roostalu H, Sepp K, et al. Assessment of abandoned agricultural land resource for bio-energy production in Estonia. Acta Agric Scand Sect B - Plant Soil Sci 2010;60:166-73. doi:10.1080/09064710902798311.

[92] Turley D, Taylor M, Laybourn R, Hughes J, Kilpatrick J, Procter C, et al. Assessment of the availability of marginal or idle land for bioenergy crop production in England and Wales. 2010.

[93] Niblick B, Landis AE. Assessing renewable energy potential on United States marginal and contaminated sites. Renew Sustain Energy Rev 2016;60:489-97. doi:10.1016/j.rser.2015.12.045.

[94] Niblick B, Monnell JD, Zhao X, Landis AE. Using geographic information systems to assess potential biofuel crop production on urban marginal lands. Appl Energy 2013;103:234-42. doi:10.1016/j.apenergy.2012.09.036.

[95] Xue S, Lewandowski I, Wang X, Yi Z. Assessment of the production potentials of Miscanthus on marginal land in China. Renew Sustain Energy Rev 2016;54:932-43. doi:10.1016/j.rser.2015.10.040.

[96] Oliver L, Ferber U, Grimski D, Millar K, Nathanail P. The Scale and Nature of European Brownfields . CABERNET 2005 - Int. Conf. Manag. urban L., Belfast: 2005.

[97] Alker S, Joy V, Roberts P, Smith N. The definition of brownfield. J Environ Plan Manag 2000;43:4969. doi:10.1080/09640560010766.

[98] Adelaja S, Shaw J, Beyea W, Charles McKeown JD. Renewable energy potential on brownfield sites: A case study of Michigan. Energy Policy 2010;38:7021-30. doi:10.1016/j.enpol.2010.07.021.

[99] Evans E. Opportunities for Biomass Production on Non-agricultural Land in the North East of England. Wilton, Redcar: 2009.

[100] Lord R, Atkinson J, Lane A, Scurlock J, Street G. Biomass, remediation, re-generation (bioregen life project): Reusing brownfield sites for renewable energy crops. In: Milind V. Khire; Akram N. Alshawabkeh; and Krishna R. Reddy, editor. GeoCongress 2008 Geotech. Waste Manag. Remediat. Geotech. Spec. Publ. 177, New Orleans: ASCE; 2008, p. 527-34. doi:10.1061/40970(309)66.

[101] Smith SL, Thelen KD, MacDonald SJ. Yield and quality analyses of bioenergy crops grown on a regulatory brownfield. Biomass and Bioenergy 2013;49:123-30. doi:10.1016/j.biombioe.2012.12.017.

[102] Klusáček P, Havlíček M, Dvorák P, Kunc J, Martinát S, Tonev P. From wasted land to megawatts: How to convert brownfields into solar power plants (the case of the Czech Republic). Acta Univ Agric Silvic Mendelianae Brun 2014;62:517-28. doi:10.11118/actaun201462030517.

[103] Donaldson R, Lord R. Can brownfield land be reused for ground source heating to alleviate fuel poverty? Renew Energy 2018;116:344-55. doi:10.1016/j.renene.2017.09.037.

[104] EPA. RE-Powering America's Land n.d. https://www.epa.gov/re-powering (accessed 27 June 2020). 
[105] Mosey G, Heimiller D, Dahle D, Vimmerstedt L, Brady-sabeff L. Converting Limbo Lands to EnergyGenerating Stations: Renewable Energy Technologies on Underused, Formerly Contaminated Sites. Cincinnati, Ohio: 2007.

[106] Waite JL. Land reuse in support of renewable energy development. Land Use Policy 2017;66:105-10. doi:10.1016/j.landusepol.2017.04.030.

[107] McKendry P. Energy production from biomass (part 1): overview of biomass. Bioresour Technol 2002;83:37-46. doi:10.1016/S0960-8524(01)00118-3.

[108] Ettala MO. Short rotation tree plantations at sanitary landfills. Waste Manag Res 1988;6:291-302. doi:10.1177/0734242X8800600145.

[109] Szabó S, Bódis K, Kougias I, Moner-Girona M, Jäger-Waldau A, Barton G, et al. A methodology for maximizing the benefits of solar landfills on closed sites. Renew Sustain Energy Rev 2017;76:1291300. doi:10.1016/j.rser.2017.03.117.

[110] Buchsbaum L. Turning Brownfields into Greenfields: From Coal to Clean Energy 2015.

[111] Rocio M, Elvira E, Pilar Z, Maria-Jose S. Could an abandoned mercury mine area be cropped? Environ Res 2013;125:150-9. doi:10.1016/j.envres.2012.12.012.

[112] WRAP. The potential for biofuel crop production on a former coal washing site in Kinglassie, Fife. Banbury, Oxon: 2009.

[113] Dubuc S. GIS-based accessibility analysis for network optimal location model: An application for bioenergy projects of the mineral Industry in the UK. Cybergeo Eur J Geogr 2007;407:1-26.

[114] Payá Pérez A, Rodríguez Eugenio N. Status of local soil contamination in Europe. 2018. doi:10.2760/093804.

[115] EEA - European Environment. Progress in management of contaminated sites - Indicator Assessment | Data and maps 2014:1-51.

[116] Panagos P, Hiederer R, Van Liedekerke M, Bampa F. Estimating soil organic carbon in Europe based on data collected through an European network. Ecol Indic 2013;24:439-50. doi:10.1016/j.ecolind.2012.07.020.

[117] News B. Report: One fifth of China's soil contaminated 2014. https://www.bbc.co.uk/news/world-asiachina-27076645 (accessed 25 June 2020).

[118] French CJ, Dickinson NM, Putwain PD. Woody biomass phytoremediation of contaminated brownfield land. Environ Pollut 2006;141:387-95. doi:10.1016/j.envpol.2005.08.065.

[119] Rawlinson H, Dickinson N, Nolan P, Putwain P. Woodland establishment on closed old-style landfill sites in N.W. England. For Ecol Manage 2004;202:265-80. doi:10.1016/j.foreco.2004.07.034.

[120] Paulson M, Bardos P, Harmsen J, Wilczek J, Barton M, Edwards D. The practical use of short rotation coppice in land restoration. L Contam Reclam 2003;11:323-38.

[121] Moffat A, Mcneill J. Forestry Commission Bulletin: Reclaiming disturbed land for forestry 1994:11,13, $14,16,70$.

[122] Pandey VC, Bajpai O, Singh N. Energy crops in sustainable phytoremediation. Renew Sustain Energy Rev 2016. doi:10.1016/j.rser.2015.09.078.

[123] Evangelou MWH, Conesa HM, Robinson BH, Schulin R. Biomass production on trace elementcontaminated land: A review. Environ Eng Sci 2012;29:823-39. doi:10.1089/ees.2011.0428.

[124] Tang YT, Deng THB, Wu QH, Wang SZ, Qiu RL, Wei Z Bin, et al. Designing Cropping Systems for Metal-Contaminated Sites: A Review. Pedosphere 2012;22:470-88. doi:10.1016/S1002-0160(12)600320 .

[125] Fortier J, Truax B, Gagnon D, Lambert F. Potential for hybrid poplar riparian buffers to provide ecosystem services in three watersheds with contrasting agricultural land use. Forests 2016;7. doi:10.3390/f7020037. 
[126] Arodudu O, Ibrahim E, Voinov A, van Duren I. Exploring bioenergy potentials of built-up areas based on NEG-EROEI indicators. Ecol Indic 2014;47:67-79. doi:10.1016/j.ecolind.2014.04.042.

[127] Van Meerbeek K, Muys B, Hermy M. Lignocellulosic biomass for bioenergy beyond intensive cropland and forests. Renew Sustain Energy Rev 2019;102:139-49. doi:10.1016/j.rser.2018.12.009.

[128] Partnership TN. Newlands: New life. New Environments. New Partnerships n.d. http://www.newlandsproject.co.uk (accessed 21 June 2020).

[129] Dudley LA. Newlands - a strateic approach to derelict, underutilised and neglected land in the Community Forests of North West England. In: Moore HM, Fox HR, Elliot S, editors. L. Reclam. Extending boundaries Proc. 7th Int. Conf. Int. Affil. L. Reclamationists, Runcorn, United Kingdom, 1316 May 2003, Lisse: A.A. Balkema, Swets \& Zeitlinger; 2003, p. 109-16.

[130] Jones K. Briefing: Newlands brownfield regeneration, UK. Proc Inst Civ Eng - Munic Eng 2010:9-14. doi:10.1680/muen.2010.163.

[131] Spiess T, De Sousa C. Barriers to Renewable Energy Development on Brownfields. J Environ Policy Plan 2016;18:507-34. doi:10.1080/1523908X.2016.1146986.

[132] Lord R, Green R, Oyekanmi E. Green waste for greening brownfields: Using compost to establish energy crops on previously developed land. Br. L. Reclaimation Soc., 2010, p. 1-6.

[133] Gomes HI. Phytoremediation for bioenergy: challenges and opportunities. Environ Technol Rev 2012;1:59-66. doi:10.1080/09593330.2012.696715.

[134] Enell A, Andersson-Skold Y, Vestin J, Wagelmans M. Risk management and regeneration of brownfields using bioenergy crops. J Soils Sediments 2016;16:987-1000. doi:10.1007/s11368-0151264-6.

[135] Seshadri B, Bolan NS, Thangarajan R, Jena U, Das KC, Wang H, et al. Biomass Energy from Revegetation of Landfill Sites. Bioremediation and Bioeconomy 2016:99-109. doi:10.1016/B978-0-12802830-8.00005-8.

[136] Lamb DT, Heading S, Bolan N, Naidu R. Use of biosolids for phytocapping of landfill soil. Water Air Soil Pollut 2012;223:2695-705. doi:10.1007/s11270-011-1060-X.

[137] Bambra C, Robertson S, Kasim A, Smith J, Cairns-Nagi JM, Copeland A, et al. Healthy land? An examination of the area-level association between brownfield land and morbidity and mortality in England. Environ Plan A 2014;46:433-54. doi:10.1068/a46105.

[138] Curtis S. Space, Place and Mental Health. Farnham, Surrey: Ashton Publishing Limited; 2010.

[139] EU. Directive (EU) 2018/2001 of the European Parliament and of the Council on the promotion of the use of energy from renewable sources. vol. 2018. 2018.

[140] Schueler V, Weddige U, Beringer T, Gamba L, Lamers P. Global biomass potentials under sustainability restrictions defined by the European Renewable Energy Directive 2009/28/EC. GCB Bioenergy 2013;5:652-63. doi:10.1111/gcbb.12036.

[141] Voivontas D, Assimacopoulos D, Koukios EG. Aessessment of biomass potential for power production: a GIS based method. Biomass and Bioenergy 2001;20:101-12. doi:https://doi.org/10.1016/S09619534(00)00070-2.

[142] Slade R, Gross R, Bauen A. Estimating bio-energy resource potentials to 2050: Learning from experience. Energy Environ Sci 2011;4:2645-57. doi:10.1039/c0ee00732c.

[143] Morrison K. Exploring The Cultural Ecosystem Services Associated With Unmanaged Urban Brownfield Sites: An Interdisciplinary (Art and Sciences) Approach. University of Salford, 2015.

[144] Plieninger T, Gaertner M. Harnessing degraded lands for biodiversity conservation. J Nat Conserv 2011;19:18-23. doi:10.1016/j.jnc.2010.04.001.

[145] Macadam CR, Bairner SZ. Urban Biodiversity: Successes and Challanges: Brownfields: oases of urban biodiversity. Glas Nat Urban Biodivers Successes Challenges 2012;25. 
[146] HMSO. Biodiveristy: The UK Action Plan. 1994.

[147] Prentis E, Norton GA. MEADOWS - an expert system for the establishment of diverse wildflower grasslands on derelict land in urban areas in the UK. Ecol Eng 1992;1:213-28. doi:10.1016/09258574(92)90003-K.

[148] Doick KJ, Hutchings T. Greenspace establishment on brownfield land: the site selection and investigation process. Edinburgh: 2007.

[149] Mathey J, Röbler S, Banse J, Lehmann I, Bräuer A. Brownfields As an Element of Green Infrastructure for Implementing Ecosystem Services into Urban Areas. J Urban Plan Dev 2015:A4015001. doi:10.1061/(ASCE)UP.1943-5444.0000275.

[150] CPRE. Housing capacity on suitable brownfield land. London: 2016.

[151] United Nations. Sustainable Development Goals n.d. https://sustainabledevelopment.un.org/?menu=1300 (accessed 28 June 2020). 